\title{
A hydrographic section from South Africa to the southern limit of the Antarctic Circumpolar Current at the Greenwich meridian
}

\author{
Sergey Gladyshev ${ }^{\mathrm{a},{ }^{*}}$, Michel Arhan ${ }^{\mathrm{b}}$, Alexey Sokov ${ }^{\mathrm{a}}$ and Sabrina Speich ${ }^{\mathrm{b}}$ \\ ${ }^{\text {a }}$ Shirshov Institute of Oceanology, Moscow, Russia \\ ${ }^{\mathrm{b}}$ Laboratoire de Physique des Océans, CNRS/IFREMER/IRD/UBO, Brest, France \\ *: Corresponding author : Sergey Gladyshev, email address : sgladyshev@ocean.ru
}

\begin{abstract}
:
The properties and circulation of water masses leaving and entering the Atlantic Ocean south of Africa are examined using data from a hydrographic and Lowered acoustic Doppler current profiler section from South Africa to the southern limit of the Antarctic Circumpolar Current (ACC). At the upper levels, the ACC fronts are well determined using either classical water mass definitions or gradient-based criteria. While the locations of the Subantarctic Front (SAF), Polar Front (PF), and Southern ACC Front (SACCF) seem controlled by the neighbouring ridges, that of the Subtropical Front (STF) is much influenced in this region $\left(\approx 10^{\circ} \mathrm{E}\right)$ by northwestward propagating Agulhas rings. No large amount of Subantarctic Mode Water (SAMW) is observed, but two varieties of vertically homogeneous water are found in eddies detached from the Agulhas retroflection: one is remotely (Indian Ocean) formed SAMW, and the other a local variety formed through winter convection in some eddies. The deep front imprints allow one to recognize lower circumpolar deep water (LCDW) from the Drake Passage (south of the SACCF), a mix of LCDW and North Atlantic Deep Water (NADW) injected in the ACC in the Argentine Basin (between the PF and STF), and diluted NADW from a southeastward pathway along the African continental slope (north of the STF in these data). The abyssal circulation, much controlled by ridges transverse to the ACC, shows a westward entry of diluted WSDW into the Cape Basin below the PF and two cyclonic patterns in the southern and central Cape Basin superimposed on a wider eastward trend. Transport estimates are given for the ACC, its fronts, and the abyssal circulation. The baroclinic and total ACC transports are $\approx 136$ and $\approx 153 \mathrm{~Sv}$, respectively. Bottom-intensified westward flows $\mathrm{O}(20 \mathrm{~Sv})$ have only a limited effect on the ACC net transport, being laterally compensated. They, however, affect the frontal structure: the $\sim 15$ Sv entry of diluted WSDW seems related to a branching of the PF, and its eastward recirculation widens the full-depth transport signature of the SAF.
\end{abstract}

Keywords: Antarctic Circumpolar Current; Agulhas eddies; Transport; Bottom circulation; Fronts; Water masses 


\section{$\underline{\text { I-Introduction }}$}

The oceanic region separating the African and Antarctic continents may be subdivided into three main regimes, namely, the subtropical domain north of $40^{\circ} \mathrm{S}-42^{\circ} \mathrm{S}$, the Antarctic Circumpolar Current (ACC) between $40^{\circ} \mathrm{S}-42^{\circ} \mathrm{S}$ and $55^{\circ} \mathrm{S}-57^{\circ} \mathrm{S}$, and the eastern part of the Weddell Sea gyre to the south (e.g. Park et al., 2001). In the subtropical region, a transfer O(10 Sv) of Indian Ocean Central Water to the Atlantic (the Agulhas leakage) is generally thought to be a key link in the global thermohaline circulation (Gordon, 1986; De Ruijter et al., 1999). Weijer et al. (2001) underlined the role of this leakage in the stability of the present day overturning circulation in the Atlantic, while at time scales of $10^{4}-10^{5}$ years Peeters et al. (2004) showed its high variability and correlation to North Atlantic Deep Water (NADW) formation. Also in the subtropical region but at depth, an export of Antarctic Bottom Water (AABW) and diluted NADW into the Indian Ocean occurs (Arhan et al., 2003). Farther south, the eastward ACC naturally contributes to inter-ocean exchange of colder water. In the Weddell Sea, finally, the flow exhibits a cyclonic recirculation pattern $\mathrm{O}(60 \mathrm{~Sv})$, yet with a westward limb exceeding the eastward one by about 5 Sv (Schröder and Fahrbach, 1999).

Despite its important role, the oceanic passage south of South Africa has been less studied than its two counterparts south of South America (the Drake Passage) and south of Australia, particularly regarding the ACC domain. In the subtropical region, the recent KAPEX and MARE programs (Richardson et al., 2003; Van Aken et al., 2003) significantly improved our knowledge of the (mostly mesoscale) processes influencing the Agulhas leakage. The ongoing German program WECCON is similarly improving our understanding of the circulation in the eastern Weddell Sea. As a complement to these studies, and in order to include the ACC in the observational effort at these longitudes, repeated samplings of a quasi-meridional hydrographic section from South Africa southward to the southern border of the ACC have been realized since 2004 in the framework of the international GoodHope project (Fig. 1), similar to those previously performed at the other choke points of the Southern Ocean (e.g. Rintoul and 
Sokolov, 2001; Cunningham et al., 2003). The GoodHope experiment includes ConductivityTemperature-Depth (CTD) measurements, geochemical tracer samplings, and expendable bathythermograph (XBT) measurements on the same and separate cruises. A part of the GoodHope section was designed to follow a groundtrack of the JASON satellite, with the aim of joining hydrographic and altimetric data analyses. ARGO floats launched during these cruises furthermore provide year-round hydrographic information on the region.

We present here observations from the first CTD cruise, conducted in November 2004 by the Shirshov Institute of Oceanology (Moscow), as part of the Meridian project, a Russian contribution to GoodHope. The cruise had several design specifications that allow us to focus on particular issues:

- One is a good spatial resolution of 20 nautical mile station spacing from the African continent to $50^{\circ} \mathrm{S}$. This provides a detailed view of the ACC fronts and a good sampling of eddies intersected in the subtropical part of the transect.

- Most of the GoodHope line lies in the south-eastern Cape Basin along (and close to) topographic ridges separating this basin from the Agulhas Basin. This yields new information on the entry of diluted Weddell Sea Deep Water (WSDW) into the Cape Basin.

- Finally, the 2004 GoodHope section is, to our knowledge, the first one providing fulldepth velocity measurements by a lowered Acoustic Doppler Current Profiler (LADCP) across the ACC in this region, from which absolute transports of this current and its fronts are estimated.

We first present the data and the vertical-latitudinal distributions of the main parameters. After a brief reminder of the water mass setting we characterize the main ACC fronts and discuss the upper ocean hydrography, which in November is still much marked by end-of-winter characteristics. We present and explain the contrasted properties of several Agulhas rings intersected during the cruise. The geostrophic transport across the section is estimated relative to 
the deepest common level (DCL) between adjacent stations and then referenced to near-bottom LADCP velocities (absolute geostrophy). As a flow of diluted WSDW is detected in the velocity sections, we finally relate this deep velocity signal to the associated water mass properties and neighbouring bathymetry.

\section{II- Data presentation and vertical sections}

The hydrographic data were collected from November $8^{\text {th }}$ to November $25^{\text {th }}$, 2004, during cruise 19 of the R/V Akademik Sergey Vavilov (ASV-19) of the Shirshov Institute of Oceanology (Cape Town Nov. $8^{\text {th }}$ to Ushuaia Dec. $9^{\text {th }}$ ). A total of 72 full-depth stations were occupied, starting at the South African continental slope at $220 \mathrm{~m}$ water depth and finishing close to the northern ice limit along the Greenwich meridian $\left(54.74^{\circ} \mathrm{S}, 0.00^{\circ} \mathrm{E}\right)$, near the location where the mid-Atlantic Ridge meets the Southwest Indian Ridge (Fig.1). A tight station spacing determined from bathymetric steps of $500 \mathrm{~m}$ and $1000 \mathrm{~m}$ was used over the South African continental slope, then set to 20 nautical miles in the deep ocean. South of $50.36^{\circ} \mathrm{S}$ a wider spacing of 40 nautical miles was maintained until the southern end of the section at $54.74^{\circ} \mathrm{S}$.

The hydrographic measurements were made using an SBE 911plus CTD system equipped with an SBE $32(24 * 12$ l) carousel providing water samples for the CTD calibration and geochemical tracer analyses. The first 51 stations were carried out using a CTD probe equipped with an oxygen sensor SBE 43. A failing of this sensor destabilized the pumping rate of water through the temperature and conductivity sensors, so that after station 51, this CTD was replaced by a spare one that had no oxygen sensor. The salinity and oxygen calibrations followed the WOCE-recommended procedures, using a total of 1178 water samples. The final CTD- $\mathrm{O}_{2}$ data uncertainties are $0.001^{\circ} \mathrm{C}, 0.002 \mathrm{psu},<5 \mu \mathrm{mol} \mathrm{kg}^{-1}$, and $<1 \mathrm{dbar}$, respectively. The accuracy of bottle oxygen data automatically titrated using the Winkler method is about $0.05 \mathrm{ml} / \mathrm{l}$ (2 $\left.\mu \mathrm{mol} * \mathrm{~kg}^{-1}\right)$. Everywhere throughout the paper we use the term temperature for potential 
temperature referenced to the sea surface, salinity is given on the practical salinity scale and density is neutral density $\gamma^{\mathrm{n}}$ in units of $\mathrm{kg} / \mathrm{m}^{3}$.

To measure velocity from the sea surface to the bottom we used a WHS $300 \mathrm{kHz}$ Sentinel LADCP installed at the lower part of the carousel frame. According to WHS $300 \mathrm{kHz}$ technical specifications a velocity standard deviation per ping is of $2 \mathrm{~cm} \mathrm{~s}^{-1}$ for a typical range $110 \mathrm{~m}$ and $8 \mathrm{~m}$ bin length. During ASV-19 cruise the ping rate was $1 \mathrm{~s}^{-1}$ with $10 \mathrm{~m}$ bin length and the lowering rate of the instrument was approximately $1 \mathrm{~m} \mathrm{~s}^{-1}$. This gives the velocity standard deviation per profile as about $0.2 \mathrm{~cm} \mathrm{~s}^{-1}$. For a cast of $4000 \mathrm{~m}$ depth (i.e., $\mathrm{n}=36$ profiles) this error accumulates as the shear profiles are tied together over the depth of the cast and is equalled $1.2 \mathrm{~cm} \mathrm{~s}^{-1}$. This estimate of the errors is too optimistic, since it neglects bias, swimmers and sea conditions. Comparison of the LADCP data with geostrophic velocity profiles in the northern part of the section, where the Rossby radius is larger than 20 nautical miles (Houry et al., 1987), suggests that the accuracy of the water track data is about $5 \mathrm{~cm} \mathrm{~s}^{-1}$. This is perhaps the realistic estimate of the accuracy. Bottom track data are accurate to better than $1 \mathrm{~cm} \mathrm{~s}^{-1}$. A geometrical sum of the water-track and bottom track LADCP data was used as a reference for geostrophic current to calculate an absolute geostrophic transport (Cunningham et al., 2003). Barotropic tide was removed from the LADCP data using the model of Egbert et al. (1994). Further in this paper baroclinic is used to refer to velocity and transport relative to a reference level or geostrophic calculation; barotropic is used to refer to the velocity at the reference level or direct LADCP measurements that also define barotropic transport.

Figure 2(a, b, c, d) shows the vertical and latitudinal distributions of potential temperature, salinity, dissolved oxygen, and neutral density, full-depth and expanded over the upper $1500 \mathrm{~m}$. Figure 3 shows the distributions of velocity perpendicular to the GoodHope line provided by the LADCP (Fig.3a) and by geostrophy corrected by the LADCP currents at the bottom (absolute geostrophy; Fig.3b). Bold signatures of the two sampled domains (subtropical region and the ACC) stand out in these sections. The presence of a subtropical domain south of 
South Africa is related to the curl of the wind stress vanishing around $45^{\circ} \mathrm{S}$, well south of the southern end of the African continent (Tomczak and Godfrey, 1994; De Ruijter et al., 1999). Subtropical water (typically warmer than $10^{\circ} \mathrm{C}$ and saltier than 35) is indeed observed north of $40^{\circ} \mathrm{S}-41^{\circ} \mathrm{S}$. The well-known mesoscale activity that characterizes the transition between the Indian and Atlantic Ocean subtropical gyres (Walker and Mey, 1988; Morrow et al., 1994; Richardson et al., 2003) is reflected in large vertical excursions of isotherms, isohalines, and isopycnals north of the same latitudes. Associated with these excursions are paired opposite velocity patterns in Figure 3. In the oxygen section, high upper layer values in the ACC domain reveal local water ventilation there, in contrast to lower values farther north marking less recently ventilated waters advected in the region by the Agulhas Current and eddy shedding process. Another characteristic of this oceanic domain is the intense heat loss to the atmosphere taking place over the warm South Indian subtropical water brought to these relatively high latitudes by the Agulhas Current (Walker and Mey, 1988; Bunker, 1988; Rouault and Lutjeharms, 2000). In Figure 2a, surface temperatures ranging from more than $20^{\circ} \mathrm{C}$ to less than $14^{\circ} \mathrm{C}$ in the subtropical domain are signs of differential heat loss by the Agulhas waters.

\section{III- Fronts and water masses}

As the water mass and frontal structures of the ACC have been widely discussed at the circumpolar scale (e.g. Orsi et al., 1995) and regionally (e.g., Sievers and Nowlin, 1984; Sokolov and Rintoul, 2002; Belkin and Gordon, 1996), including along the Greenwich meridian (Whitworth and Nowlin, 1987), we limit the following discussion of fronts and water masses along the ASV-19 line to two specific aspects, namely, i) a comparison of classic fronts indicators (Orsi et al., 1995) with indicators based on property gradients and ii) the effect of the ACC zonation on the deep water distribution. 


\section{Upper-layer front indicators}

Orsi et al. (1995) reviewed and synthesized previously used criteria for the ACC fronts and proposed a set of indicators for these and the ACC meridional limits thought to apply at all longitudes (their Table 3). These indicators, expressed as $\theta$, S or $\mathrm{O}_{2}$ values generally marking water mass boundaries at certain depths, provide locations for the Subtropical Front (STF), the Subantarctic Front (SAF), the Polar Front (PF) and the Southern ACC Front (SACCF) as reported on Figures 1 to 3. The STF is located at stations 30-31 of ASV-19 (40.07 $\left.\mathrm{S}-40.37^{\circ} \mathrm{S}\right)$, very close to the climatological track proposed by Orsi et al. (1995) from the pre-1990 data (Fig.1). The SAF between stations 44 and $45\left(44.12^{\circ} \mathrm{S}-44.4^{\circ} \mathrm{S}\right)$, on the other hand, lies about 3 degrees to the north of the climatologic location, a likely result of the lack of pre-1990 CTD data in this region, which led Orsi et al. (1995) to propose an SAF track south of the Meteor Rise (Fig.1) rather than north of it. The finding of the SAF north of this bathymetric feature along ASV-19 corroborates previous results obtained from surface temperatures along neighbouring lines (Lutjeharms and Valentine, 1984) and from expendable bathythermograph (XBT) lines (Lutjeharms, 1985; Legeais et al., 2005). The PF is found between $50.36^{\circ} \mathrm{S}$ and $50.88^{\circ} \mathrm{S}$ (ASV19 stations 65-66) just north of a local 2000 m-high escarpment on the equatorward flank of the mid-ocean ridge. This location is identical to the one found by Whitworth and Nowlin (1987) in their analysis of the AJAX cruise data along the Greenwich meridian. Following Orsi et al. (1995) and other researchers, we placed the PF at the northern end of the domain where a shallow ( $<200 \mathrm{~m}$ ) temperature minimum can be found (Fig.2a). This, however, leads to some ambiguity, as a detached volume of water colder than $2^{\circ} \mathrm{C}$ could suggest a position shifted northward by about one degree. An examination of satellite altimetry Sea Surface Height (SSH) maps showed that this two-step structure of the PF is a local feature. In the following we call this northern expression of the PF the Northern PF (NPF), located at stations 61-62 (49.02$\left.49.41^{\circ} \mathrm{S}\right)$. The SACCF location $\left(52.75^{\circ} \mathrm{S}-53.45^{\circ} \mathrm{S}\right.$, stations $\left.69-70\right)$ right above the top of the mid-ocean ridge, is also similar to that deduced by Orsi et al. (1995) from the AJAX section. The 
last ASV-19 station was carried out at $54.75^{\circ} \mathrm{S}$, close to the northernmost annual ice extension limit along the Greenwich meridian. The ACC southern boundary probably laying a few tens of nautical miles to the south (Whitworth and Nowlin, 1987) was not reached in 2004.

The ACC limits and fronts are, by definition, associated with lateral gradients of water properties. For a more detailed examination of these fronts, we show the along-track gradients of $\theta, \mathrm{S}$, and $\gamma^{\mathrm{n}}$ at depths $10 \mathrm{~m}, 100 \mathrm{~m}$, and $400 \mathrm{~m}$ in Figure 4(a,b,c). The gradients of dynamic height $\mathrm{DH}_{50 / 2000}$ at $50 \mathrm{~m}$ relative to $2000 \mathrm{~m}$ are displayed in Figure 4d. Each figure panel further shows the frontal locations deduced from the criteria of Orsi et al. (1995). Disregarding the thermohaline variability of the subtropical domain (north of $\sim 39^{\circ} S$ ), we observe that welldefined maxima of the gradients of $\theta, \mathrm{S}$, and $\gamma^{\mathrm{n}}$ mark the STF at 10 and $400 \mathrm{~m}$. A salinity gradient also exists at $100 \mathrm{~m}$, but a more widespread temperature rise at this depth hinders the detection of the STF from the $\theta$ and $\gamma^{\mathrm{n}}$ gradients. The STF gradient signatures are still pronounced at $400 \mathrm{~m}$. An examination of Figure 2 even suggests a bottom-reaching STF, in contrast to observations south of Australia (Rintoul and Trull, 2001) that showed a front limited to the upper few hundred meters. This deep-reaching character of the STF may be explained by the presence of eddies detached from the retroflection of the Agulhas Current (Agulhas rings). Figure 2 shows that an eddy, centred at station 27 and recognizable from its bowl-shaped signature, indeed set the STF location along the track of ASV-19. In Figure 3, the LADCP section confirms the bottom-reaching signature of this eddy, yet with a reversal of azimuthal velocity near $2000 \mathrm{~m}$. Observing that the STF may be located at the border of propagating eddies (a situation already observed by Lutjeharms and Valentine, 1988) raises the question of the stability and continuity of the front in this region. Maps of sea surface height (SSH) deduced from satellite altimetry (e.g., Boebel et al., 2003) illustrate the eddy activity likely influencing the frontal pattern, but suggest a decrease of this influence west of $\sim 10^{\circ} \mathrm{E}$. While the observation reported here is from $10.5^{\circ} \mathrm{E}$, another hydrographic section along the Greenwhich meridian (Whitworth and Nowlin, 1987) displays STF signatures only reaching downward to 2000 m. 
The SAF is well recognized from $\theta$ and S gradients at $10 \mathrm{~m}$ and $100 \mathrm{~m}$-depth (Fig.4a,b). It is remarkable, however, that no significant density gradient marks the SAF at these depths, reflecting compensating effects of the $\theta$ and $\mathrm{S}$ northward rises across the front. Such densitycompensating variations of $\theta$ and $\mathrm{S}$ across the SAF were underlined by Rintoul and England (2002) in the region south of Australia and are thought to favour water exchange across the front in the surface mixed layer, notably through northward Ekman transport. The cross-SAF situation is very different at $400 \mathrm{~m}$, for this depth lies in the layer where Antarctic Intermediate Water (AAIW) formed in the Polar Frontal Zone is injected into the Subantarctic Zone. As a result, the cross-SAF salinity gradient is weak at this depth, leaving the $\theta$ and associated $\gamma^{\mathrm{n}}$ gradients as the main SAF indicators.

The $\theta$ and $\mathrm{S}$ upper-layer gradients are not very pronounced at the PF but, opposite to what occurs at the SAF, the northward temperature increase and salinity decrease combine into significant density gradients at the three sampled depths. The cross-SACCF gradients are also weak, particularly the salinity one, making it difficult to detect this front using these indicators.

The lateral gradients of $\mathrm{DH}_{50 / 2000}$, finally, appear as good indicators of all ACC fronts, and corroborate the locations deduced from the other criteria. The quantity $\mathrm{DH}_{50 / 2000}$ even clearly marks the NPF around $49.5^{\circ} \mathrm{S}$. While the currents associated with the SAF and PF are generally observed to dominate the ACC flow, Figure 4d suggests an STF flow comparable to those of the major fronts. Unlike the latter, however, the intense STF flow should not be totally associated with an eastward transport. As this front was detected at the border of an eddy, a part of its associated flow should be ascribed to the eddy azimuthal velocities.

\section{Upper water masses in relation to fronts}

Proceeding northward from the southern end of the section, the first water mass encountered in the upper layer is the Winter Water (WW) of the Antarctic Zone (the region south of the Polar front). South of the SACCF this water is found in a 200 m-thick winter surface 
mixed layer with negative temperatures, salinities lower than 34, and oxygen concentrations in excess of $270 \mu \mathrm{mol} / \mathrm{kg}$ (Figure 2). Capping of the WW by the seasonal thermocline had not yet started in this region in November 2004. It is only weakly apparent between the SACCF and the $\mathrm{PF}$, there resulting in a temperature minimum at 150 -200 m depth. While the fresh upper water $(S<34)$ extends northward to the SAF, the underlying salinity structure best reflects the meridional transition of dynamical regime that occurs near the PF. South of this front, the vertical transition between WW and the underlying Circumpolar Deep Water (CDW) is marked by a pronounced halocline at $200 \mathrm{~m}$ depth, indicative of a deep water upwelling in the regime of surface Antarctic divergence. The halocline is much weaker north of the PF, where a downward/northward bulging of the salinity contours reveals downwelling. Similar patterns of the oxygen contours (Figure 2c) corroborate this conclusion. These observations are in agreement with a vanishing of the Ekman divergence near $50^{\circ} \mathrm{S}$ along the Greenwich meridian (Tomczak and Godfrey, 1994). The change of dynamical regime at the Polar Front is reflected in the salinity distribution (Figure 2b) through higher near-surface salinities south of the PF resulting from an injection of underlying CDW into the surface mixed layer.

The near-surface water of the Polar Frontal Zone is the least saline near-surface water in the ACC band. It is observed continuously at all longitudes (e.g. Orsi and Whitworth, 2005) and subducts northward at the SAF to feed the AAIW. At south Australian longitudes Rintoul and Trull (2001) observed a northward transfer of surface water from the Polar Frontal Zone across the SAF into the Subantarctic Zone. The ASV-19 section suggests that this also occurs southwest of South Africa, as a surface layer of fresh and oxygenated water is seen extending northward across the Subantarctic Zone (Fig.2b,c). Closer examination shows that this water is fresher in the southern half and upper $50 \mathrm{~m}$ of the Subantarctic Zone, corroborating the idea of a transfer through Ekman drift. This near-surface low salinity water north of the SAF, probably combined with an incipient seasonal thermocline, results in a well-defined upper layer stratification (Fig.2d). High oxygen values (>250 $\mu \mathrm{mol}^{*} \mathrm{~kg}^{-1}$ ) down to about $200 \mathrm{~m}$ in the Subantarctic Zone, 
however, suggest that during winter the thin fresh layer intruding from the south is mixed with the underlying water to form a $\sim 200$-m thick mixed layer. The $8^{\circ}-9^{\circ} \mathrm{C}$ thermostads observed at stations 37 and 43 might be remnants of this winter mixed layer but, at variance with the situation south of Australia (Rintoul and Trull, 2001), the ASV-19 section shows no significant volume of Subantarctic Mode Water (SAMW) in the Subantarctic Zone. The same observation can be made on the neighbouring hydrographic sections, e.g. AJAX (Whitworth and Nowlin, 1987), WOCE/A12 (Lemke, 1994), and WOCE/A21 (Roether et al., 1990). This also matches McCartney's (1977) presentation of the longitudinal distribution of SAMW at $30^{\circ} \mathrm{S}$. The latter study showed, however, that a small amount of SAMW is present in the eastern South Atlantic, yet with temperatures of $12-15^{\circ} \mathrm{C}$, not $8-9^{\circ} \mathrm{C}$ as at stations 37 and 43 . Other thermostads (12 $13^{\circ} \mathrm{C}$ ) present north of the STF are discussed in the next section.

\section{Lower water masses in relation to fronts}

The ASV-19 sections display the well-known deep water mass arrangement of the ACC (e.g. Sievers and Nowlin, 1984; Whitworth and Nowlin, 1987), composed of low oxygen Upper Circumpolar Deep Water (UCDW), high salinity Lower Circumpolar Deep Water (LCDW), and Weddell Sea Deep Water (WSDW). In the northern part of the section the deep salinity maximum is not associated with LCDW, but with diluted North Atlantic Deep Water (NADW) leaving the Atlantic southeastward along the African continental slope (Arhan et al., 2003). Here we focus on the meridional structure of this deep tongue of high salinity, and defer an analysis of the flow and properties of the bottom water to the last section. Examination of the deep $\theta-S$ diagram of all ASV-19 stations (Figure 5) reveals a series of station groups separated by gaps representative of the deep expressions of the fronts.

Although associated with two different water masses (LCDW and NADW), the salinity maximum shows nearly similar densities along the entire section $\left(\gamma^{\mathrm{n}}=28.06 \pm 0.02\right)$. It is lower than 34.72 south of the SACCF, and lower than 34.74 south of the PF. Whitworth and Nowlin 
(1987) and Naveira Garabato et al. (2002) observed that 34.73 is about the highest value found in Drake Passage, so that the deep saline water found south of the PF at the Greenwich meridian should be considered as LCDW having gone through the Drake Passage, whereas the more saline water north of this front reveals a NADW influence. This NADW-influenced deep water itself exhibits several varieties. This is deduced from the observation that the $\theta$-S curves of the stations north of the PF (salinity maxima higher than 34.75) are mostly grouped in two bunches (Fig. 5). The first one, corresponding to the Polar Frontal Zone, has salinity maxima between 34.75 and 34.79. The other one, north of the STF, has maxima higher than 34.83. The Subantarctic Zone exhibits somewhat more widespread salinity maxima. From Whitworth and Nowlin (1987), the first group should be ascribed to NADW injected in the ACC in the southwestern Argentine Basin, whose influence has reached the PF by the time it arrives at the Greenwich meridian. The closeness of the PF and SAF at longitudes around 35W (Orsi et al., 1995; Heywood and King, 2002) probably favours the poleward transfer of NADW influence to the PF and explains the station grouping in the Polar Frontal Zone at the Greenwich meridian. The other bunch of stations in Figure 5 (salinity maxima higher than 34.83 north of the STF) corresponds to the other NADW pathway out of the Atlantic, first eastward across the ocean at $20^{\circ} \mathrm{S}-25^{\circ} \mathrm{S}$, then southeastward along the African slope (Arhan et al., 2003). Figures $2 b$ and 5 suggest that the water from this deep slope current spreads southwestward to the neighbourhood of the STF, likely owing to the intense mesoscale turbulence of the Cape Basin. Such a relation between the STF and the deep water distribution, however, might again be due to the above-mentioned role of bottom-reaching eddies in determining the location of the STF in this area. Examination of the deep $\theta$-S diagrams of neighbouring hydrographic sections (AJAX, WOCE/A12, WOCE/A21) also revealed a grouping of the highest deep maximum salinities ( $\mathrm{S}>34.83$ ) corresponding to the eastern NADW pathway, yet not always as strictly related to the STF as on ASV-19. At AJAX and WOCE/A12, for instance, salinity maxima of about 34.84 south of the STF show that the influence of the eastern NADW may penetrate the Subantarctic Zone. 


\section{$\underline{\text { IV-Agulhas rings intersected by ASV-19 }}$}

Thermohaline and altimetric ring signatures

The subtropical region intersected by the ASV-19 cruise is a well-known domain of high eddy kinetic energy (e.g. Wakker et al., 1990; Goni et al., 1997) crossed by anticyclonic Agulhas rings detached from the Agulhas Current retroflection and by cyclones generated at the STF or near the South African continental slope (Richardson et al., 2003). The presence of three major bowl-shaped features in the subtropical parts of the $\theta, \mathrm{S}$, and $\gamma^{\mathrm{n}}$ distributions (E1, E2, and E3 in Figures 2a,b,d) is therefore not a surprise. Although such patterns likely signal Agulhas rings in this region, we observe significant property differences between E1 and E2, on the one hand, and E3 on the other hand. While the two former show relatively stratified cores with temperatures up to $18^{\circ} \mathrm{C}$ (for E1) and $16^{\circ} \mathrm{C}$ (for E2) and no oxygen signal distinguishing them from the 220 $\mu \mathrm{mol} / \mathrm{kg}$ background values, E3 has a pronounced thermostad (pycnostad) at $12.5^{\circ} \mathrm{C}\left(\gamma^{\mathrm{n}}=26.75\right)$ associated with a high oxygen anomaly of more than $250 \mu \mathrm{mol} / \mathrm{kg}$. This suggests a different history of the three eddies with likely recent winter convection in the core of E3. In order to try and corroborate this inference, we used a time series of sea surface height (SSH) to visualize the eddies at the time of the cruise (Fig.6a) and determine their trajectories by back-tracking their surface signatures (Fig.6b). We used absolute SSH values combining a multi-satellite sea surface anomaly (TOPEX-POSEIDON, JASON-1, ERS; Le Traon et al., 1998; Ducet et al., 2000) and a mean dynamic topography itself combining in-situ data, altimetric data, and the EIGENGRACE03S geoid (Rio and Hernandez, 2004). Figure 6a shows that the cruise track went through the northern and western sides of E1 (hence its apparent large width in Fig.2) and through the eastern side of E2 (actually a ridge linking it to E1). Eddy E3 is recognized as an eddy of smaller size that the cruise track intersected close to its centre. Its SSH value ( 1.8 dyn. m) is smaller than those of E1 and E2 (>2 dyn. m), in keeping with this structure being subsurface intensified, as visible from its associated lens-shaped isopycnals in Figure 2d. 


\section{Ring histories}

Rings E1 and E2 originated as a single Agulhas ring that detached from the retroflection in early August 2004 (Fig.6b). Like many other rings, it formed just east of the eastern end of the Agulhas Ridge and, when propagating westward, was subdivided on encountering this bathymetric obstacle (Arhan et al., 1999; Schouten et al., 2000). The resulting northern part of the eddy rapidly moved northwestward and was itself split in two parts in October 2004, giving birth to E1 and E2. This recent splitting explains the SSH ridge still linking the two eddies at the time of the cruise in Figure 6a. In the same Figure, the southern part of the initial ring is observed at $42^{\circ} \mathrm{S}-14^{\circ} \mathrm{E}$. The rapid northwestward escape of E1/E2 from the retroflection region in the austral late winter and spring period is in keeping with their having vertical structures close to that of the Agulhas Current (e.g. Gordon et al., 1987).

Eddy E3 also originated from the subdivision of a newly spawned Agulhas ring in December 2003/January 2004 (Fig.7). Contrary to E1/E2, however, E3 is the southern product of the subdivision. Figure 7c shows that, a few weeks after its formation, E3 found itself at a rather high latitude $\left(\sim 43^{\circ} \mathrm{S}\right)$, well within the subantarctic zone, and to the southeast of the Agulhas Ridge. Figure $6 \mathrm{~b}$ shows that this eddy stalled south of $42^{\circ} \mathrm{S}$ for the whole autumn and winter, and only managed to cross the Agulhas Ridge northward in September 2004. Intense heat loss to the atmosphere during this period (Olson et al., 1992; Rouault and Lutjeharms, 2000) certainly led to the peculiar core properties of this eddy.

Using the indicator of Orsi et al. (1995) for the STF led us to locate this front at the southern border of E3 along the track of cruise ASV-19 (Fig. 2, 6a). However, another sharp SSH gradient is present north of E3, and southeast of E2, in Figure 6a. The SSH maps showed that E3 was just re-entering the subtropical domain at the time of the cruise, and, had the cruise taken place two weeks earlier, the STF would have been located north of E3, at the southern border of E2. 
Lutjeharms and Valentine (1988) described four categories of eddies formed in the vicinity of the STF south of Africa, which they distinguished from Agulhas rings. From the above description, E3 falls in their "warm eddies" category generated at the Agulhas retroflection. This study shows that some of these "warm eddies" observed in the subantarctic zone close to the Agulhas retroflection result from the splitting of an initial Agulhas ring and, after first moving southward, eventually proceed northwestward into the Atlantic Ocean. Considering their behaviour, these eddies should probably be considered as Agulhas rings.

\section{Eddy water masses}

For a further analysis of the water masses contained in the eddies, we show in Figure 8 a diagram of squared Brunt-Väisälä frequency $\left(\mathrm{N}^{2}\right)$ versus $\theta$ for all ASV-19 stations north of the STF. The diagram displays pycnostads at $12.5^{\circ} \mathrm{C}$ (very intense), around $12^{\circ} \mathrm{C}$ (less pronounced), and at $13.2{ }^{\circ} \mathrm{C}$ and $14.5^{\circ} \mathrm{C}$ (still weaker). The one at $12^{\circ} \mathrm{C}$ corresponds to the central station of E1. This pycnostad, which is part of the Indian Ocean Central Water trapped in the eddy, corresponds to a vertical oxygen maximum (Fig.9a). It has the exact properties of Subantarctic Mode Water (SAMW) present in the retroflection loop south of Africa (Gordon et al., 1987) and formed at longitudes around $60^{\circ} \mathrm{E}$ in the south Indian Ocean (McCartney, 1977). This water is injected in the southern Indian Ocean subtropical circulation and conveyed to the retroflection area, where it may be pinched off in rings. Figure 9a, showing the vertical profiles of $\theta, \mathrm{S}$ and $\mathrm{O}_{2}$ at the central station of E1, shows properties for this remotely-formed SAMW very similar to those observed by van Aken et al. (2003) in another Agulhas ring.

The most pronounced pycnostad in Figure 8 corresponds to the core of E3. It reveals a situation of neutral stability in this eddy at the time of the cruise, another confirmation of recent winter convection. This particular structure of the vertical profiles of E3 (fig.9b), and the above deduction from the trajectory that this homogeneous water was formed in the Subantarctic Zone, suggest that it be regarded as a particular kind of SAMW specific to this region, and resulting 
from the excursion of some Agulhas rings in the Subantarctic Zone. We do not mean, however, that this water is a volumetric mode in the studied region. First, its formation mechanism in eddies is unlikely to produce large quantities of water. Second, depending on the duration and period of the year that the eddies spend in the Subantarctic Zone, they re-enter the subtropical domain with variable properties: the cooled ring sampled during ASV-19 shows a $12.5{ }^{\circ} \mathrm{C}$ thermostad, but other cooled structures previously sampled in the eastern South Atlantic had different temperatures of $13^{\circ} \mathrm{C}$ (McDonagh and Heywood, 1999), $13.5^{\circ} \mathrm{C}$ (Garzoli et al., 1999), and $11.6^{\circ} \mathrm{C}$ and $13^{\circ} 6^{\circ} \mathrm{C}$ (Arhan et al., 1999).

\section{Eddy velocities}

Van Aken et al. (2003) made a detailed study of a newly-formed ring and, using LADCP measurements, observed a strong barotropic component in the ring azimuthal velocities, with values still exceeding $0.1 \mathrm{~m} / \mathrm{s}$ at $4000 \mathrm{~m}$-depth. Examination of Figure 3 shows that the same applies to rings E1 and E2 which, like the ring described van Aken et al. (2003), had not experienced strong interaction with the bathymetry when sampled. Kamenkovich et al. (1996) and Beismann et al. (1999) showed that eddies with a barotropic velocity component are hindered in crossing a bathymetric ridge. The initial barotropic velocity component of Agulhas rings therefore explains why the newly-formed ring E3 was blocked by the Agulhas Ridge for several months. Although the same ring still exhibits a near-bottom velocity signal when sampled after crossing the bathymetry, this signature is reversed (i.e. cyclonic) relative to its upper circulation. The crossing of the ridge may be a reason for this difference, although it is not clear how this occurs: Kamenkovich et al. (1996) found that an eddy crossing a ridge becomes more baroclinic, which is observed for E3, though in an extreme way. Herbette et al. (2005) showed that the interaction of a surface eddy with a seamount can generate deep structures of both signs that can subsequently couple with the initial one. 
Figure 3a also shows that, contrary to the surface-intensified features E1 and E2, the azimuthal velocities in E3 are most intense at $~ 300 \mathrm{~m}$, as could be inferred from the reversal of isopycnal slopes at this depth in Figure 2d. On re-entering the subtropical domain, the eddy is bound to encounter lighter water and subduct beneath it (Herbette et al., 2004), a process that apparently had already started when the eddy was sampled. As another difference, the highest cross-track velocities measured in E3 are $0.3 \mathrm{~m} / \mathrm{s}$, lower than those across E1 and E2 (0.4 - 0.5 $\mathrm{m} / \mathrm{s}$ ), although the former were measured in the eddy core, and the latter near the eddy rims. This confirms previous observations by Arhan et al. (1999) of weaker rotational velocities in rings that have crossed the Agulhas Ridge.

Determining the thickness of water trapped in an eddy is difficult. Theoretically, this thickness depends on the ratio of the eddy drift velocity and the depth-dependent eddy tangential velocity (Flierl, 1981). This ratio is itself time-dependent. Water mass contrasts between a ring interior and its surroundings may also be useful indicators of the trapping thickness. Van Aken et al. (2003) observed that, for their well-sampled ring, such contrasts were only detected above about $600 \mathrm{~m}$, a rather low value for a 2-month old ring. A more favorable water mass configuration indicates that, when sampled during ASV-19, E3 was still trapping water down to about 1000 m. In Figure 2c, a parcel of intermediate water with oxygen values lower than 220 $\mu \mathrm{mol} / \mathrm{kg}$ is observed below the eddy northern flank. From the better-resolved SBE-43 oxygen data available at this location (not shown), this turned out to be a V-shaped feature extending downward to $1000 \mathrm{~m}$ and obviously attached to the eddy. This is intermediate water from the Indian Ocean, surrounded by more oxygenated ambient intermediate water of Atlantic origin (Gordon et al., 1992). Had E3 been sampled a few degrees to the north $\left(<37^{\circ} \mathrm{N}\right)$, where the ambient water is also from the Indian Ocean, the contrast would not have been apparent. This observation therefore reveals a trapping thickness of at least $1000 \mathrm{~m}$, although E3 was sampled nearly 11 months after its formation, and had crossed the Agulhas Ridge (at a position where this ridge rises to $\sim 2500-3000 \mathrm{~m}$ depth). 


\section{V-ACC Transport}

In this section we examine the structure and magnitude of the volume transport across the ASV-19 line. The flow structure in the ACC and subtropical domain is analysed from the crosssection LADCP (Fig.3a) and absolute geostrophy velocity (Fig.3b) fields. The discussion on the transports rests on the baroclinic transport assuming zero velocity at the deepest common level (DCL) of station pairs (Fig.10a and continuous curve of Fig.10b), and on the absolute geostrophy transport referenced to near-bottom LADCP measurements (Fig.11 and stippled curve of Figure 10b). Further, we compare our results with the results at other choke-point sections in Drake Passage (Cunningham et al., 2003) and south of Australia (Rintoul and Sokolov, 2001). Although the ASV-19 section did not cross the southern ACC boundary, we believe that a transport there is small and does not exceed 5-10 Sv (Schröder and Fahrbach, 1999).

Determining the ACC northern boundary to estimate the transport may be done according to different criteria. In the preceding sections focused on water properties, we followed the usual assumption of an ACC domain bounded northward at the STF. When considering the ACC flow, we rather choose to limit the ACC northward at $43^{\circ} \mathrm{S}$, which corresponds to the northern boundary of the SAF. This choice, which rests on the view of the ACC as an eastward transport band, is suggested by the presence of a westward flow at $42^{\circ} \mathrm{S}-43^{\circ} \mathrm{S}$, an apparently permanent feature in this region, also observed in subsurface floats measurements (Richardson, 2007) and other CTD samplings (Whitworth and Nowlin, 1987).

\section{Baroclinic transport}

The ACC baroclinic transport occurs mainly at four fronts (Figure 3). The SAF is the northernmost one at $44.5^{\circ} \mathrm{S}$ that corresponds to a southeastward current between $43^{\circ} \mathrm{S}$ and $45^{\circ} \mathrm{S}$, with a peak velocity around $0.4 \mathrm{~m} / \mathrm{s}$. This current penetrates to the bottom, although the intensive flow is limited to the upper $1000 \mathrm{~m}$. The SAF flow is the biggest contributor to the ACC volume transport, reaching $68 \mathrm{~Sv}$ (Figure 10a). The PF at 51.5 $\mathrm{S}$ and the NPF at $50^{\circ} \mathrm{S}$ have similar 
current structures with peak velocities exceeding $0.2 \mathrm{~m} / \mathrm{s}$ in the upper $300 \mathrm{~m}$. Their transports are $23.9 \mathrm{~Sv}$ and $25 \mathrm{~Sv}$, respectively. Finally, the SACCF, located at $53^{\circ} \mathrm{S}$, is not characterized by a strong eastward current, and the transport within this front is only $8.0 \mathrm{~Sv}$. The intervals between the fronts show weak baroclinic transports (Fig.10a), either eastward as in the Polar Frontal Zone (11.2 Sv), or westward between the PF and NPF, and north of the SAF as noted above. In the next section we analyze the westward ACC flows more carefully in relation to the bottom topography.

The ACC transport integrated between $54.74^{\circ} \mathrm{S}$ and $43^{\circ} \mathrm{S}$ is $136 \mathrm{~Sv}$ (Figure 10b). This value is close to other estimates of the ACC baroclinic transport relative to the DCL (or relative to the best guess level across SR3) in other Southern Ocean regions (Table 1). The somewhat larger baroclinic estimate south of Tasmania (section SR3 in Table 1) might reflect a necessary compensation for the O(10 Sv) Indonesian Throughflow (Rintoul and Sokolov, 2001). Tracking the main front contributions to the ACC transport from Drake Passage to the South Pacific, however, we note an increase in the contribution of the SAF, especially impressive as the ACC flows through the Indian Ocean. While the SAF and PF contributions to the ACC baroclinic transport remain comparable in the Atlantic, the SAF transport is about three times that of the PF in the Pacific (Table 1). In contrast, the contribution of the PF to the total ACC baroclinic transport decreases after the current passes the western South Atlantic.

North of the ACC along ASV-19, the structure of the baroclinic transport in the subtropical domain is determined mostly by the Agulhas eddies (Fig.10). The baroclinic transport signatures of these vortices exhibit asymmetries (10 to $20 \mathrm{~Sv}$, relative to eddy signals around $50 \mathrm{~Sv}$ ), likely reflecting background larger scale circulation features (Agulhas leakage, South Atlantic Current, and likely weak baroclinic signatures of deeper flows). The net baroclinic transport north of $43^{\circ} \mathrm{S}$ is about $30 \mathrm{~Sv}$ northwestward (across the southwest-oriented part of the section) or northward (across the zonal segment). 


\section{Total transport}

Geostrophy modified by adding the barotropic component measured with LADCP near the bottom gives a somewhat different picture of the current structure south of Africa (Fig.10b, Fig.11). Most pronounced changes are the westward highly barotropic current north of the PF southern branch clearly seen in Figure 3, the intensification of the eastward flow in the Polar Frontal Zone, and the presence of a bottom-intensified westward component beneath the STF leading to a westward full-depth transport at the location of this front.

The total (absolute geostrophy) ACC transport is $153 \mathrm{~Sv}$, or $13 \%$ higher than the baroclinic transport. The westward flow between the two PF branches is considerably larger (28 Sv; Fig. 11) than its baroclinic counterpart. This westward flow is located at the northern flank of the mid-Atlantic Ridge (MAR), suggesting a topographic control. Direct LADCP measurements reveal both surface and bottom intensifications of this current (Figure 3a). Laterally, the westward transport around $51^{\circ} \mathrm{S}$ is compensated by mostly eastward barotropic flows south of $46^{\circ} \mathrm{S}$ (Figure 10b). This compensation is due to a significant increase of the eastward transport in the Polar Frontal Zone relative to the baroclinic estimation. As a result, the apparent SAF width is much larger in Figure 11 than in Figure 10a.

Proceeding northward, the westward flow at $42^{\circ} \mathrm{S}-43^{\circ} \mathrm{S}$ mentioned above from the baroclinic transport curve is still present in the total transport. Its location above the northern flank of the Agulhas Ridge (Fig.3b) and its likely permanent character, also noted above, suggest a bathymetric control of this flow. Still farther north, the transport signatures of E1, E2 and E3 are also strongly modified by referencing the geostrophy to observed abyssal velocities. The asymmetry of the eddy transport signatures is strongly increased after the barotropic flow component is taken into account, an indication of a significant abyssal circulation. The most important effect is on E3, whose previous anticyclonic signature at $38.5^{\circ} \mathrm{S}-41^{\circ} \mathrm{S}$ in the baroclinic transport diagram (Fig.10a) reverses into a cyclonic pattern in the distribution of barotropic transports (Fig.11). In Figure 3b, opposite bottom-intensified velocities exceeding $0.1 \mathrm{~m} / \mathrm{s}$ on 
either side of $39^{\circ} \mathrm{S}$ suggest the presence of a deep cyclone beneath E3, possibly coupled with the latter. This deep vortex obviously dominates the top-to-bottom integrated transport, leading to the cyclonic signature visible in Figure 11 between $38.5^{\circ} \mathrm{S}$ and $41^{\circ} \mathrm{S}$.

Comparing Figures 10a and 11, the barotropic part of the flow increases the transport of the SACCF by a ratio of 1.5 to $\sim 12$ Sv. The total transports of the PF and NPF increase by factors of 1.2 and 1.3 relative to their baroclinic values, reaching $30 \mathrm{~Sv}$ and $33 \mathrm{~Sv}$, respectively. The westward transport of $28 \mathrm{~Sv}$ between the PF and NPF approximately equals the barotropic eastward transport in the Polar Frontal Zone, resulting in the lateral compensation mentioned above. In the subtropical domain, the non-compensation of the azimuthal eddy transports is more pronounced than with baroclinic velocities. For instance, the calculated transport difference in E1 is $45 \mathrm{~Sv}$. The integrated northward/northwestward flow north of the STF is $25 \mathrm{~Sv}$.

\section{$\underline{\text { VI- Bottom water circulation and transport }}$}

The observation of a significant barotropic transport component across the ASV-19 section, and the close vicinity of the ridges separating the Agulhas Basin and the Cape Basin (Fig.1) raise the question of possible bathymetric effects on the abyssal circulation in this region. From analyses of water mass properties by Mantyla and Reid (1983) and Orsi et al. (1999), it appears that the deepest waters in the Cape Basin are in the density range $28.18<\gamma^{\mathrm{n}}<28.27 \mathrm{~kg} / \mathrm{m}^{3}$ of LCDW, not of WSDW $\left(\gamma^{\mathrm{n}}>28.27 \mathrm{~kg} / \mathrm{m}^{3}\right)$. Although the ASV-19 density section supports this conclusion, a close examination of bottom water property distributions in the WOCE hydrographic atlas (Orsi and Whitworth, 2005) suggests that a part of the WSDW that leaves the Weddell-Enderby basin near $30^{\circ} \mathrm{E}$ through the Southwest Indian Ridge (SWIR) further proceeds westward along the northern flank of this ridge, toward and into the Cape Basin. This westward branch is clearly shown in a schematic map of regional bottom circulation in Reid (1989; his Fig.31), which further suggests a large cyclonic abyssal flow in the Cape Basin. Figure 2(a,b,d), showing a bottom layer of colder $\left(\theta<0.5^{\circ} \mathrm{C}\right)$, fresher $(\mathrm{S}<34.7)$, and denser $\left(\gamma^{\mathrm{n}}>28.22\right)$ water over 
the northern slope of the mid-Atlantic Ridge (MAR), is another confirmation of the westward branch of WSDW and its entry into the Cape Basin. The fact that this water has properties beyond the strict ranges associated with WSDW is indicative of a rapid mixing of the westward WSDW branch with the surrounding LCDW. The strong vertical and lateral shears implied by the eastward ACC surroundings certainly favour such mixing, particularly as a westward deep flow against the northern flank of the SWIR and MAR should be parallel with, and close to, the PF and SACCF (Fig.1).

In the deep $\theta$-S diagram (Fig.5), a gap in the bottom properties separates stations 42-71, associated with the newer bottom waters above the slope of the MAR, from the apparently older bottom waters of stations 6-41 farther north. The Agulhas Ridge at $43^{\circ} \mathrm{S}$ separates the two groups. "Pure" WSDW $\left(\theta<0.3^{\circ} \mathrm{C}\right)$ is found only at the three stations located south of the SACCF. Farther north, the $\theta$-S bottom values of the new abyssal waters (stations 41-72) are relatively widespread $\left(0.2<\theta<0.5^{\circ} \mathrm{C}, 34.68<\mathrm{S}<34.71\right)$, suggesting incomplete mixing and multiple pathways from the Weddell Sea to the location of ASV-19, first through the SWIR, then through the Shona Ridge located a short distance east of the cruise track (Fig.1). In addition to the main exit from the Weddell Sea located near $30^{\circ} \mathrm{E}$ in the SWIR, Reid (1989) suggests that the fracture zone at $\sim 4^{\circ} \mathrm{E}$ separating the MAR and the SWIR (Fig.1) might be another passage. Figure 12 (lower part) showing the depth along the crestline of Shona Ridge shows two passages deeper than $3000 \mathrm{~m}$, through this ridge at $49^{\circ} \mathrm{S}$ and between this ridge and the Meteor Rise, that could be taken by the densest diluted WSDW to enter the Cape Basin. At $50^{\circ} \mathrm{S}$ on $\mathrm{ASV}-19$, bottom-intensified westward LADCP velocities exceeding $0.1 \mathrm{~m} / \mathrm{s}$ signal the flow of new bottom water downstream of these passages.

The northern group of stations (6-41) in Figure 5 exhibits a tighter $\theta$-S relationship than the stations south of the Agulhas Ridge. The bottom values themselves show weak dispersion around $\theta=0.6^{\circ} \mathrm{C}$ and $\mathrm{S}=34.72$, and the linear relation of the waters colder than $\sim 2^{\circ} \mathrm{C}$ suggests mixing between the diluted WSDW and the NADW present north of the STF. The nearly closed 
character of the abyssal Cape Basin and the basin-wide cyclonic bottom circulation (including possible recirculation in the central basin) certainly favour vertical mixing between the modified WSDW entering the basin in the south and the overriding warmer and more saline waters entering it from the west and north. As discussed in section III, the latter are themselves twofold: Between the PF and SAF, they should be regarded as a blend of LCDW from the Drake Passage and NADW injected into the ACC in the Argentine Basin. North of the STF the saline deep waters are NADW entering the Cape Basin from the northwest. The deep $\theta$-S diagram suggests a dominant influence of the latter NADW pathway on the abyssal waters of the central Cape Basin.

In an attempt to summarize the abyssal circulation in the region, we present in Figure 13 the latitudinal distributions of transports and meridionally integrated transports across ASV-19. A schematic interpretation of the main patterns is proposed in Figure 12. For this computation we set the upper boundary of the abyssal waters at the isotherm $1.5^{\circ} \mathrm{C}$, which, north of the Agulhas Ridge, is about the middle of the thermocline separating the deep waters from the colder fresher bottom waters. As this limit corresponds to $\gamma^{\mathrm{n}}=28.13$ north of the Agulhas Ridge and 28.1 south of the ridge, the bottom layer thus defined is somewhat thicker than the one obtained from the $\gamma^{\mathrm{n}}>28.18$ density range of Orsi et al. (1999).

With this definition, a westward abyssal flow of $\sim 15 \mathrm{~Sv}$ is observed around $50^{\circ} \mathrm{S}$. The above analysis of the bottom thermohaline properties suggests that a part of this westward flow recirculates in the southern Cape Basin (itself a nearly closed abyssal sub-basin south of $45^{\circ} \mathrm{S}$ ) and contributes to the $26 \mathrm{~Sv}$ eastward transport observed between $50.5^{\circ} \mathrm{S}$ and the SAF at $45^{\circ} \mathrm{S}$. The amount of recirculating water is uncertain, as a part of the $15 \mathrm{~Sv}$ flow probably proceeds westward along the MAR and cyclonically in the central Cape Basin, according to the circulation scheme of Reid (1989). Similarly, the outflowing transport of $26 \mathrm{~Sv}$ south of $45^{\circ} \mathrm{S}$ is also necessarily partly fed by water from west of the MAR. It is unlikely that the westward flow of WSDW against the northern flank of the SWIR amounts to $15 \mathrm{~Sv}$. In order to reach this transport 
value across ASV19, additional constituents are required. One might be a cyclonic recirculation west of the Shona Ridge, as indicated by a stippled line in Figure 12. Another one might be LCDW entrained in the westward flow along the SWIR.

Figure 13b shows that the abyssal eastward flow associated with the ACC spans latitudes from $50.5^{\circ} \mathrm{S}$ (north of the westward branch of diluted WSDW) to $43^{\circ} \mathrm{S}$. Because of the observed differences in the water thermohaline properties (Fig.5), however, the part of this transport taking place north of the SAF (7 Sv) should not be regarded as a recirculation of the WSDW, but as old bottom water arriving from the northern Cape Basin (marked in red in Figure 12).

Although the abyssal transport in the northern part of the section is perturbed by the deep imprints of the eddies, a northwestward component of $\sim 25 \mathrm{~Sv}$ at $39^{\circ} \mathrm{S}-43^{\circ} \mathrm{S}$ and a net southeastward flow of $28 \mathrm{~Sv}$ north of $39^{\circ} \mathrm{S}$ may be inferred from Figure $13 \mathrm{~b}$. This allows us to propose a circulation pattern for the old bottom water (red in Figure 12). The proposed flow schematic in the southeastern Cape Basin matches the basin-wide cyclonic flow pattern of Reid (1989) and suggests two southeastward exits on either side of the Agulhas Ridge. The cyclonic flow in the central Cape Basin and the previously described one south of $45^{\circ} \mathrm{S}$ appear in Figure $13 \mathrm{~b}$ as two bowl-shaped patterns $\left(35^{\circ} \mathrm{S}-43^{\circ} \mathrm{S}\right.$ and $\left.45^{\circ} \mathrm{S}-51.5^{\circ} \mathrm{S}\right)$ superimposed on the wider eastward trend below the ACC and in the subtropical domain. Considering only the latitudes north of $52^{\circ} \mathrm{S}$, the net eastward flow of abyssal waters across ASV-19 is about $20 \mathrm{~Sv}$, which should be accounted for by the deep water entries from the west and northwest. The transport of bottom water leaving the Cape Basin between the Agulhas Ridge and the African continental slope is about $3 \mathrm{~Sv}$, which is compatible within the given range of uncertainty with the $\sim 5 \mathrm{~Sv}$ value obtained from inverse model computations by Arhan et al. (2003).

\section{$\underline{\text { VII- Conclusions }}$}

The ACC as sampled during ASV-19 exhibits the classical frontal structure composed of the three bottom-reaching SAF, PF, and SACCF and with the PF observed as a two-branch 
feature. The irregular bathymetry separating the Cape Basin and the Agulhas Basin seems to influence the front locations, with the SAF located at the gap between the Agulhas Ridge and the Meteor Rise and the PF located above the steep northern flank of the mid-Atlantic Ridge. Welldefined $\theta$ and S meridional gradients mark the SAF and PF at $10 \mathrm{~m}$ and $100 \mathrm{~m}$-depths, particularly pronounced for the SAF, yet with a nearly total density-compensating effect. The SACCF is most visible through near-surface $\theta$ and density gradients. North of the ACC, the STF defined from classical thermohaline indicators was found at the southern border of an Agulhas ring, a frequent situation in this transitional region where the South Atlantic and South Indian subtropical gyres are connected by these northwestward propagating eddies. As a consequence the density signature of the STF observed during ASV-19 is bottom-reaching, at variance with its vertical structure at other longitudes. Another consequence is the extreme meandering of the STF in this region.

The estimated baroclinic geostrophic transport of the ACC ( 136 Sv relative to bottom) falls in the range of previous estimates in this region, with frontal contributions also comparable and a baroclinic SAF transport exceeding the PF transport by about $20 \mathrm{~Sv}$. The ACC transport estimated using absolute geostrophy (referenced to near-bottom LADCP velocities) is $153 \mathrm{~Sv}$, with significant structure changes relative to the baroclinic computations. A bottom-intensified westward flow below the PF is likely related to the two-branch behaviour of this front, and a deep eastward transport in the Polar Frontal Zone extends the full-depth SAF transport signature southward over a $500 \mathrm{~km}$-wide band. Another westward flow observed north of the SAF at the upper and intermediate levels, and corroborated by previous lagrangian measurements, seems a permanent feature.

The abyssal westward flow beneath the PF marks an entry of diluted WSDW in the Cape Basin along the northern flank of the MAR. Sharp lateral gradients of abyssal water properties near the Meteor Ridge suggest that most of this new abyssal water recirculates cyclonically in the southern Cape Basin. North of these gradients, the near-bottom circulation inferred in the 
central Cape Basin matches another cyclonic flow suggested by Reid (1989). The two cyclonic patterns stand out in the distribution of meridionally integrated full-depth transport, superimposed on an eastward trend that amounts to $\sim 20 \mathrm{~Sv}$ for $\theta<1.5^{\circ} \mathrm{C}$ between $52^{\circ} \mathrm{S}$ and the African continental slope.

Unlike the hydrographic transects in Drake Passage or south of Australia, the ASV-19 section shows no large volume of SAMW north of the SAF. An examination of the water properties in the cores of Agulhas rings intersected north of the STF nevertheless reveals that two varieties of vertically homogeneous water may be conveyed by these structures to the southeastern Atlantic, though likely in small quantity. One is relatively old SAMW from the South Indian Ocean, well known to be present in the Agulhas retroflection and the detached rings. The other variety is formed locally through winter convection in some Agulhas rings that transit at high latitudes $\left(>40^{\circ} \mathrm{S}\right)$. While such southward excursions of some rings have long been observed (Lutjeharms and Valentine, 1988), the altimetric backtracking of ring E3 observed during the cruise confirms the role played by the Agulhas Ridge in splitting some newly-formed rings and in blocking the southern portion of the subdivision into the subantarctic zone, thus favouring heat loss to the atmosphere. Ring E3 eventually managed to cross the ridge northward, but a comparison of its velocity signal with those of the other intersected rings suggests a stronger erosion of the rings that follow this southern track. When observed nearly one year after its formation, E3 nevertheless still had its original intermediate water trapped to at least $1000 \mathrm{~m}$ depth, and previous observations have shown that these cooled rings may survive to the vicinity of the mid-Atlantic Ridge as they further propagate northwestward. Lutjeharms (1988) pointed out the contribution of these southward propagating subtropical eddies to the meridional heat transport across the STF. The contribution to this transport of rings like E3 which return to the subtropical domain with a high trapping thickness must be weak relative to that of other structures totally eroded in the ACC. The significant erosion of E3 inferred from its azimuthal 
velocities is likely to be dominated by its heat loss to the atmosphere rather than by exchanges with the surrounding subantarctic waters.

\section{Acknowledgements:}

S. Gladyshev and A. Sokov were supported by the multidisciplinary, interdepartmental project "Meridian” of the Russian Federal program "World Ocean”. The contributions of M. Arhan and S. Speich were supported by the Institut Français de Recherche pour l'Exploitation de la Mer (IFREMER), the Université de Bretagne Occidentale (UBO), and the Centre National de la Recherche Scientifique (CNRS). The aid of $\mathrm{Ph}$. Le Bot in the preparation of the Figures is acknowledged. Valuable comments of two reviewers are deeply appreciated. 


\section{References}

Arhan M., Mercier H., Lutjeharms J.R.E., 1999. The disparate evolution of three Agulhas rings in the South Atlantic Ocean. Journal of Geophysical Research, 104, 20987-21005.

Arhan M., Mercier H., Park Y.-H., 2003. On the Deep Water circulation of the eastern South Atlantic Ocean. Deep-Sea Research Part I, 50, 889-916.

Beismann J.-O., R.H. Käse, J.R.E. Lutjeharms, 1999. On the influence of submarine ridges on translation and stability of Agulhas rings. Journal of Geophysical Research, 104, 78977906.

Belkin I.M., Gordon A.L., 1996. Southern Ocean fronts from the Greenwich meridian to Tasmania. Journal of Geophysical Research, 101, 3675-3696.

Boebel O., Barron C., 2003. A comparison of in situ float velocities with altimeter derived geostrophic velocities. Deep-Sea Research Part II, 50, 119-139.

Bunker A.F., 1988. Surface energy fluxes of the South Atlantic Ocean. Monthly Weather Revews, 116, 809-823.

Cunningham S.A., Alderson S.G., King B.A., Brandon M.A., 2003. Transport and variability of the Antarctic Circumpolar Current in Drake Passage. Journal of Geophysical Research, 108(C5), 8084, doi:10.1029/2001JC001147.

De Ruijter W.P.M., Biastoch A., Drijfhout S.S., Lutjeharms J.R.E., Matano R.P., Pichevin T., van Leeuwen P.J., Weijer W., 1999. Indian-Atlantic interocean exchange: Dynamic, estimation and impact. Journal of Geophysical Research, 104, 20885-20910.

Ducet N., Le Traon P.Y., Reverdin G., 2000. Global high-resolution mapping of ocean circulation from TOPEX/Poseidon and ERS-1 and -2. Journal of Geophysical Research, 105, 19477-19498. 
Egbert G.D., Bennett A.F., Foreman M.G.G., 1994. TOPEX/POSEIDON tides estimated using a global inverse model. Journal of Geophysical Research, 99, 24821-24852.

Flierl G.L., 1981. Particle motions in large-amplitude wave fields. Geophysical and Astrophysical Fluid Dynamics, 18, 39-74.

Garzoli S.L., Richardson P.L., Duncombe Rae C.M., Fratantoni D.M., Goni G.J., Roubicek A.J., 1999. Three Agulhas rings observed during the Benguela Current Experiment. Journal of Geophysical Research, 104, 20971-20985.

Goni G.J., Garzoli S.L., Roubicek A.J., Olson D.B., Brown O.B., 1997. Agulhas ring dynamics from TOPEX/POSEIDON satellite altimeter data. Journal of Marine Research, 55, 861883.

Gordon A.L., 1986. Interocean exchange of thermocline water. Journal of Geophysical Research, 91, 5037-5046.

Gordon A.L., Lutjeharms J.R.E., Gründlingh M.L., 1987. Stratification and circulation at the Agulhas retroflection. Deep-Sea Research, 34, 565-599.

Gordon A.L., Weiss R.F., Smethie W.M., Warner M.J., 1992. Thermocline and intermediate water communication between the South Atlantic and Indian Oceans. Journal of Geophysical Research, 97, 7223-7240.

Herbette S., Morel Y., Arhan M., 2004. Subduction of a surface vortex under an outcropping front. Journal of Physical Oceanography, 34, 1610-1627.

Herbette S., Morel Y., Arhan M., 2005. Erosion of a surface vortex by a seamount on the $\beta$ plane. Journal of Physical Oceanography, 35, 2012-2030.

Heywood K.J., King B.A., 2002. Water masses and baroclinic transports in the South Atlantic and Southern oceans. Journal of Marine Research, 60, 639-676. 
Houry S., E. Dombrowsky, P. De Mey, J.F. Minster, 1987: Brunt-Väisälä frequency and Rossby radii in the South Atlantic. Journal of Physical Oceanography, 17, 1619-1626.

Kamenkovich V.M., Leonov Y.P., Nechaev D.A., Byrne D.A., Gordon A.L., 1996. On the influence of bottom topography on the Agulhas eddy. Journal of Physical Oceanography, 26, 892-912.

Legeais J.F., Speich S., Arhan M., Ansorge I., Fahrbach E., Garzoli S., Klepikov A., 2005. The baroclinic transport of the Antarctic Circumpolar Current south of Africa. Geophysical Research Letters, 32, L24602, doi: 10.1029/2005GL023271.

Lemke P., 1994. The expedition ANTARKTIS X/4 of the research vessel «Polarstern» in 1992, Ber. Polarforsch., 140, 90 pp.

Le Traon P.Y., F. Nadal and N. Ducet, 1998: An improved mapping method of multisatellite altimeter data. Journal of Atmospheric and Oceanic Technology, 15, 522-534.

Lutjeharms J.R.E., 1985. Location of frontal systems between Africa and Antarctica: Some preliminary results. Deep-Sea Research, 32, 1499-1509.

Lutjeharms J.R.E., 1988. Meridional heat transport across the Sub-tropical Convergence by a warm eddy. Nature, 331, 251-254.

Lutjeharms J.R.E. and H.R. Valentine, 1984. Southern Ocean thermal fronts south of Africa. Deep-Sea Research, 31, 1461-1475.

Lutjeharms J.R.E., Valentine H.R., 1988. Eddies at the Subtropical Convergence south of Africa. Journal of Physical Oceanography, 18, 761-774.

Mantyla A.W., Reid J.L., 1983. Abyssal characteristics of the world ocean waters. Deep-Sea Research, 30, 805-833.

McCartney M.S., 1977. Subantarctic Mode Water. In Angel M.V. (Ed.), A Voyage of Discovery, George Deacon 70 ${ }^{\text {th }}$ Anniversary volume, Pergamon, New York, pp. 103-119. 
McDonagh E.L., Heywood K.J., 1999. The origin of an anomalous ring in the southeast Atlantic. Journal of Physical Oceanography, 29, 2050-2064.

Morrow R., Coleman R., Church J., Chelton D., 1994. Surface eddy momentum flux and velocity variances in the Southern Ocean from Geosat altimetry. Journal of Physical Oceanography, 24, 2050- 2071.

Naveira Garabato A.C., Heywood K. J., Stevens D.P., 2002. Modifications and pathways of Southern Ocean Deep Waters in the Scotia Sea. Deep-Sea Research, 49, 681-705.

Olson D.B., Fine R., Gordon A.L., 1992. Convective modifications of water masses in the Agulhas. Deep-Sea Research Part A, 39, Supplement, 163-181.

Orsi A.H., Johnson G.C., Bullister J.L, 1999. Circulation, mixing, and production of Antarctic Bottom Water. Progress in Oceanography, 43, 55-109.

Orsi A.H., Whitworth T. III, Nowlin W.D., 1995. On the meridional extent and fronts of the Antarctic Circumpolar Current. Deep-Sea Research, 42, 641-673.

Orsi A.H., Whitworth T. III, 2005. Hydrographic Atlas of the World Ocean Circulation Experiment (WOCE). Volume 1: Southern Ocean (eds. M. Sparrow, P. Chapman and J. Gould), International WOCE project Office, Southampton, U.K., ISBN 0-904175-49-9.

Park Y.-H., Charriaud E., Craneguy P., 2001. Fronts, transport, and Weddell Gyre at $30^{\circ} \mathrm{E}$ between Africa and Antarctica. Journal of Geophysical Research, 106, 2857-2879.

Peeters F.J.C., Acheson R., Brummer G.-J. A., de Ruijter W.P.M., Schneider R.R., Ganssen G.M., Ufkes E., Kroon D., 2004. Vigorous exchange between the Indian and Atlantic oceans at the end of the past five glacial periods. Nature, 430, 661-665.

Reid J.L., 1989: On the total geostrophic circulation of the South Atlantic Ocean: Flow patterns, tracers, and transports. Progress in Oceanography, 23, 149-244. 
Richardson P.L., 2007. Agulhas leakage into the Atlantic estimated with subsurface floats and surface drifters. Deep-Sea Research I, 54, 1361-1389.

Richardson P.L., Lutjeharms J.R.E., Boebel O., 2003. Introduction to the "Inter-ocean exchange around southern Africa”. Deep-Sea Research Part II, 50, 1-12.

Rintoul S.R., England M.H., 2002. Ekman transport dominates local air-sea fluxes in driving variability of Subantarctic Mode Water. Journal of Physical Oceanography, 32, 13081321.

Rintoul S.R., Trull T.W., 2001. Seasonal evolution of the mixed layer in the Subantarctic Zone south of Australia. Journal of Geophysical Research, 106, 31447-31462.

Rintoul S.R., Sokolov S., 2001. Baroclinic transport variability of the Antarctic Circumpolar Current south of Australia (WOCE repeat section SR3). Journal of Geophysical Research, 106, 2795-2814.

Rio M.H., Hernandez F., 2004. A mean dynamic topography computed over the world ocean from altimetry, in situ measurements, and geoïd model. Journal of Geophysical Research, 109, C12032, doi: 10.1029/2003JC002226.

Roether W., Sarnthein M., Müller T.J., Nellen W., Sahrhage D., 1990. SüdatlantikZircumpolarstrom, Reise Nr 11, 3 Oktober 1989 - 11 März 1990, Meteor.-Ber. 90-2, 169 pp., Univ. Hamburg, Hamburg, Germany.

Rouault M., Lutjeharms J.R.E., 2000. Air-Sea exchange over an Agulhas eddy at the subtropical convergence. Global Atmosphere and Ocean System, 7, 125-150.

Schouten M.W., de Ruijter W.P.M., van Leeuwen P.J., Lutjeharms J.R.E., 2000. Translation, decay and splitting of Agulhas rings in the southeastern Atlantic Ocean. Journal of Geophysical Research, 105, 21913-21925. 
Schröder M., Fahrbach E., 1999. On the structure and the transport of the eastern Weddell gyre. Deep-Sea Research Part II, 46, 501-527.

Sievers H.A., Nowlin W.D., 1984. The stratification and water masses at Drake Passage. Journal of Geophysical Research, 89, 10489-10514.

Sokolov S., Rintoul S.R., 2002. Structure of Southern Ocean fronts at $140^{\circ}$ E. Journal of Marine Systems, 37, 151-184.

Tomczak M., Godfrey J.S., 1994. Regional Oceanography: An introduction. Pergamon Press, $422 \mathrm{pp}$.

Van Aken H.M., van Veldhoven A.K., Veth C., de Ruijter W.P.M., van Leeuwen P.J., Drijfhout S.S., Whittle C.P., Rouault M., 2003. Observation of a young Agulhas ring, Astrid, during MARE in March 2000. Deep-Sea Research Part II, 50, 167-195.

Wakker K.F., Zanbergen R.C.A., Naeije M.C., Ambrosius B.A.C., 1990. Geosat altimeter data analysis for the oceans around South Africa. Journal of Geophysical Research, 95, 29913006.

Walker N.D., Mey R.D., 1988. Ocean/atmosphere heat fluxes within the Agulhas retroflexion region. Journal of Geophysical Research, 93, 15473-15483.

Weijer W., de Ruijter W.P.M., Dijkstra H., 2001. Stability of the overturning circulation: Competition between Bering Strait fresh water flux and Agulhas heat and salt sources. Journal of Physical Oceanography, 31, 2385-2402.

Whitworth T. and W.D. Nowlin, 1987: Water masses and currents of the Southern Ocean at the Greenwich Meridian. Journal of Geophysical Research, 92, 6462-6476. 


\begin{tabular}{|c|c|c|c|c|c|}
\hline Location & SAF & PF & SACCF & Total-SB & Reference \\
\hline SR1 (Drake Passage) & $57.5 \pm 5.7$ & $53 \pm 10$ & $9.3 \pm 2.4$ & $136.7 \pm 7.8$ & $\begin{array}{c}\text { Cunningham et al., } \\
2003\end{array}$ \\
\hline $\begin{array}{c}\text { A23 (Western South } \\
\text { Atlantic) }\end{array}$ & 57 & 66.9 & 17.8 & $141.7^{*}$ & $\begin{array}{c}\text { Heywood and King, } \\
2002\end{array}$ \\
\hline $\begin{array}{c}\text { SR2 (GoodHope) } \\
\text { SR3 (South of Australia) }\end{array}$ & $105 \pm 7$ & $29 \pm 6$ & $29 \pm 4$ & $147 \pm 10^{* *}$ & $\begin{array}{c}\text { Rintoul and Sokolov, } \\
2001\end{array}$ \\
\hline
\end{tabular}

Table 1: Comparison of the ACC geostrophic transports (in Sv, relative to DCL) at different longitudes. The reported A23 total transport is the sum of the three main front transports (SAF, PF and SACCF). The SR3 total transport estimate includes the transport associated with the ACC Southern Boundary. 


\section{Figures:}

Figure 1: Map showing the ASV-19 cruise track, station numbers, bathymetry (isobaths $200 \mathrm{~m}$ and multiples of $1000 \mathrm{~m}$ ), and the ACC fronts. STF (Subtropical Front), SAF (Subantarctic Front), PF (Polar front) and SACCF (Southern ACC Front) mark the locations of these fronts as determined from the criteria summarized in Orsi et al. (1995). The black lines show the climatological paths of the same fronts and of the ACC southern boundary, as proposed by the same authors. MAR stands for mid-Atlantic Ridge, and SWIR for southwest Indian Ridge.

Figure 2: Vertical distributions of potential temperature $\theta$ (a), salinity $S(b)$, dissolved oxygen $\mathrm{O}_{2}$ (c), and neutral density $\gamma^{\mathrm{n}}$ (d), expanded in the 0-1500 m depth range. The $\mathrm{O}_{2}$ section uses the bottle data shown by dots. Horizontal axis is distance, with latitude reported. Station locations are shown by triangles. Also displayed are the positions of the fronts, the locations of three eddies (E1, E2, E3) north of $40^{\circ} \mathrm{S}$, and the upper limit $\left(\theta=1.5^{\circ} \mathrm{C}\right)$ of the bottom water layer studied in section VI.

Figure 3: (a) Vertical distribution of LADCP velocity component perpendicular to the cruise track (positive and non-shaded to the south-east), with the front positions, indication of eddies E1, E2, E3, and the upper limit of bottom water. (b) Same as (a) for the geostrophic velocity referenced to near-bottom LADCP values (absolute velocity).

Figure 4: Lateral gradients of potential temperature (a), salinity (b), density (c), and dynamic height at 50 dbar relative to 2000 dbar (d), along the ASV-19 cruise track, at $10 \mathrm{~m}, 100$ $\mathrm{m}$, and $400 \mathrm{~m}$. The front locations deduced from the criteria of Orsi et al. (1995) are indicated by triangles.

Figure 5: Deep $\theta$-S diagram of all ASV-19 stations, limited by $S=34.60$. Different colors mark the subtropical domain and ACC frontal zones. The deep salinity maxima (black dots), their adjusted second order polynomial (black curve), and corresponding average $\gamma^{\mathrm{n}}$ value are reported. The vertical line at $S=34.73$ gives the maximum salinity in Drake Passage. The two station groups 6-41 and 42-71 illustrate the change of bottom properties across the Agulhas Ridge.

Figure 6: a) Sea surface height (SSH) field at the time of the cruise, showing eddies E1, E2 and E3. The cruise track and locations of the STF and SAF are superimposed. b) Map with shaded bathymetry showing the cruise track and trajectories of E1, E2, E3, with dates.

Figure 7: Sequence of SSH maps showing the formation of eddy E3 (31/12/03, 21/1/04, 4/2/04). The black thick stippled line schematises the Agulhas Ridge. 
Figure 8: Diagram of squared Brunt-Väisälä frequency versus temperature for stations north of the STF and temperature range $9-16^{\circ} \mathrm{C}$. Stations 9 (blue) and 24 to 29 (red) are shown by coloured continuous lines (instead of dots) to emphasize the homogeneous cores of E1 and E3.

Figure 9: Vertical profiles of $\theta, \mathrm{S}$, and $\mathrm{O}_{2}$ in eddies E1 (a) and E3 (b).

Figure 10: (a) Cross-track baroclinic transport (geostrophy referenced to DCL). Positive is southeastward (southward) across the northeastward (zonally) oriented part of the section. (b) Along-track integrated transport of baroclinic velocities (continuous) and absolute geostrophic velocities (stippled). Vertical lines at $43^{\circ} \mathrm{S}$ show the northern limit used for ACC transport computations.

Figure 11: Cross-track transport of absolute geostrophic velocities (referenced to near-bottom LADCP velocities). The vertical line at $43^{\circ} \mathrm{S}$ marks the northern limit used for ACC transport computations.

Figure 12: Top panel: Proposed schematic circulation of layer $\theta<1.5^{\circ} \mathrm{C}$, with transport estimates in Sverdrup. Also shown are the bottom LADCP velocity vectors.

Middle panel: Cross-track bottom LADCP velocities (positive eastward and southward). Lower panel: Bathymetry along the crest-line separating the Cape Basin and Agulhas Basin. The track of this line is shown in the top panel. Vertical arrows show possible deep passages for bottom currents.

Figure 13: (a) Cross-track absolute transport (computed using absolute geostrophic velocities) in the bottom layer $\theta<1.5^{\circ} \mathrm{C}$. (b) Along-track integrated transport of layer $\theta<1.5^{\circ} \mathrm{C}$. Vertical lines at $43^{\circ} \mathrm{S}$ show the northern ACC boundary. 


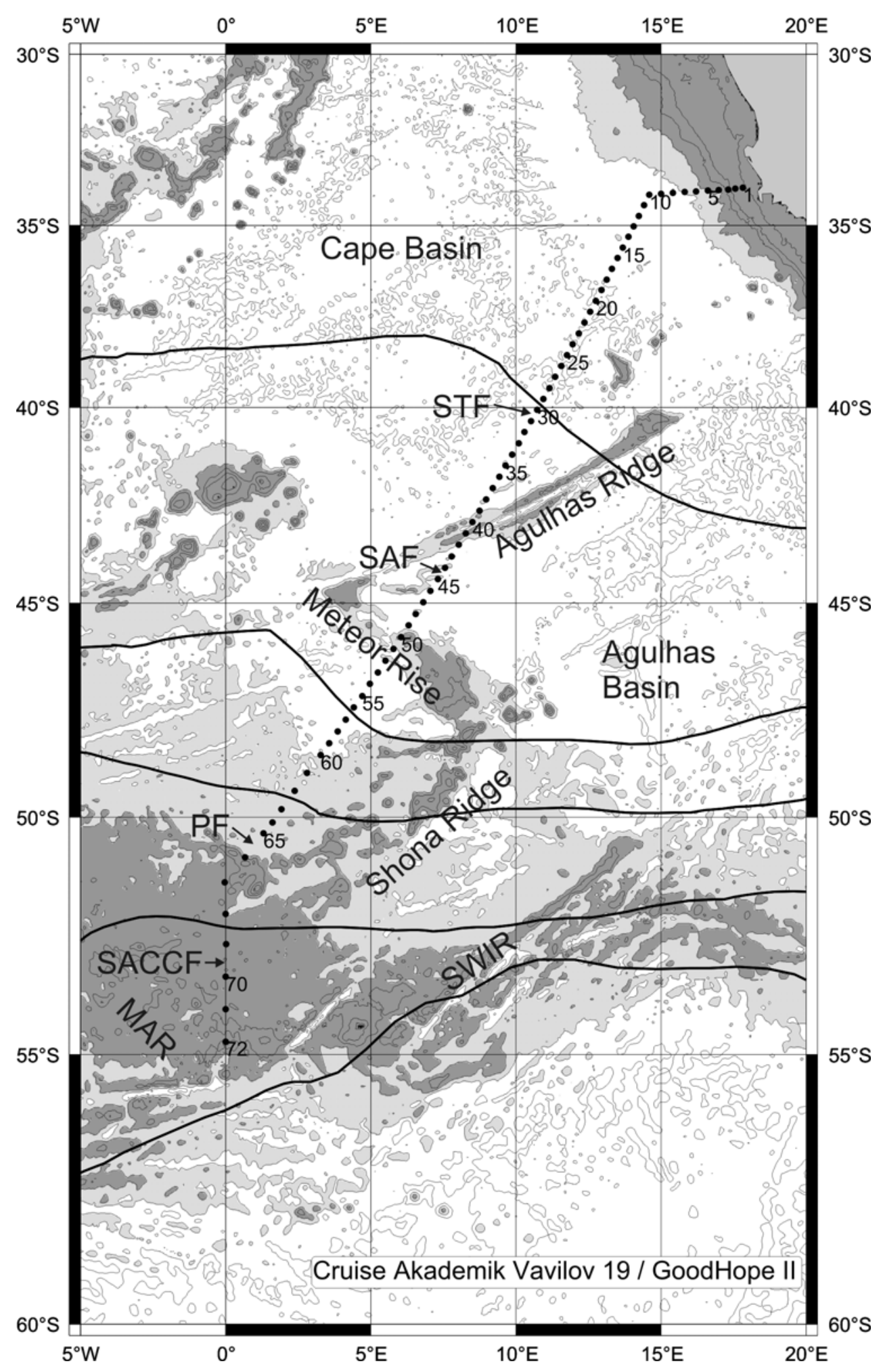

Figure 1 : Map showing the ASV-19 cruise track, station numbers, bathymetry ( isobaths $200 \mathrm{~m}$ and multiples of $1000 \mathrm{~m}$ ), and the ACC fronts. STF (Subtropical Front), SAF (Subantarctic Front), PF (Polar front) and SACCF (Southern ACC Front) mark the locations of these fronts as determined from the criteria summarized in Orsi et al. (1995). The black lines show the climatological paths of the same fronts and of the ACC southern boundary, as proposed by the same authors. MAR stands for mid-Atlantic Ridge, and SWIR for southwest Indian Ridge. 


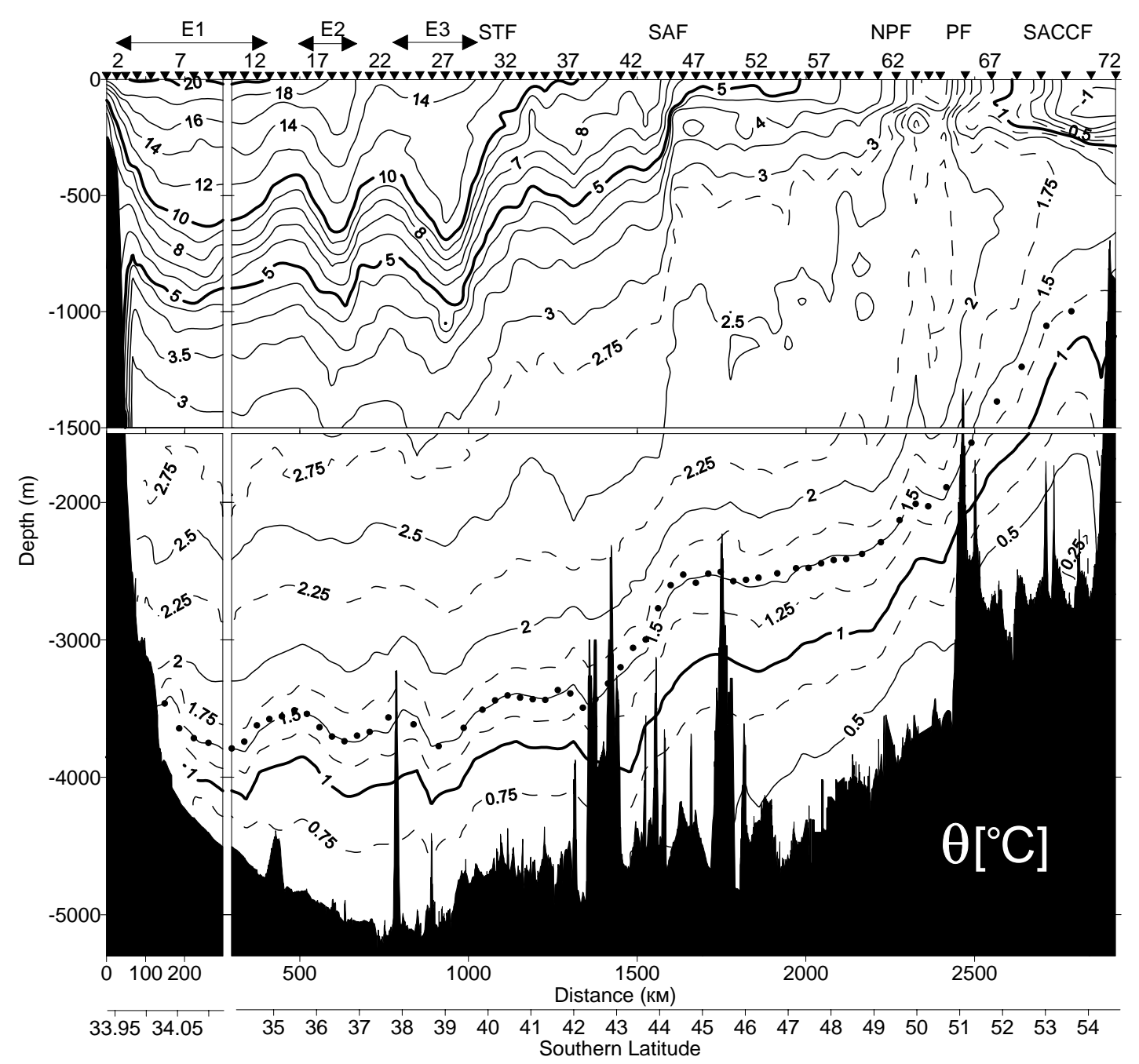

Figure 2a

Figure 2: Vertical distributions of potential temperature $\theta$ (a), salinity $S(b)$, dissolved oxygen $\mathrm{O}_{2}$ (c), and neutral density $\gamma^{\mathrm{n}}$ (d), expanded in the 0-1500 m depth range. The $\mathrm{O}_{2}$ section uses the bottle data shown by dots. Horizontal axis is distance, with latitude reported. Station locations are shown by triangles. Also displayed are the positions of the fronts, the locations of three eddies (E1, E2, E3) north of $40^{\circ} \mathrm{S}$, and the upper limit $\left(\theta=1.5^{\circ} \mathrm{C}\right)$ of the bottom water layer studied in section VI. 


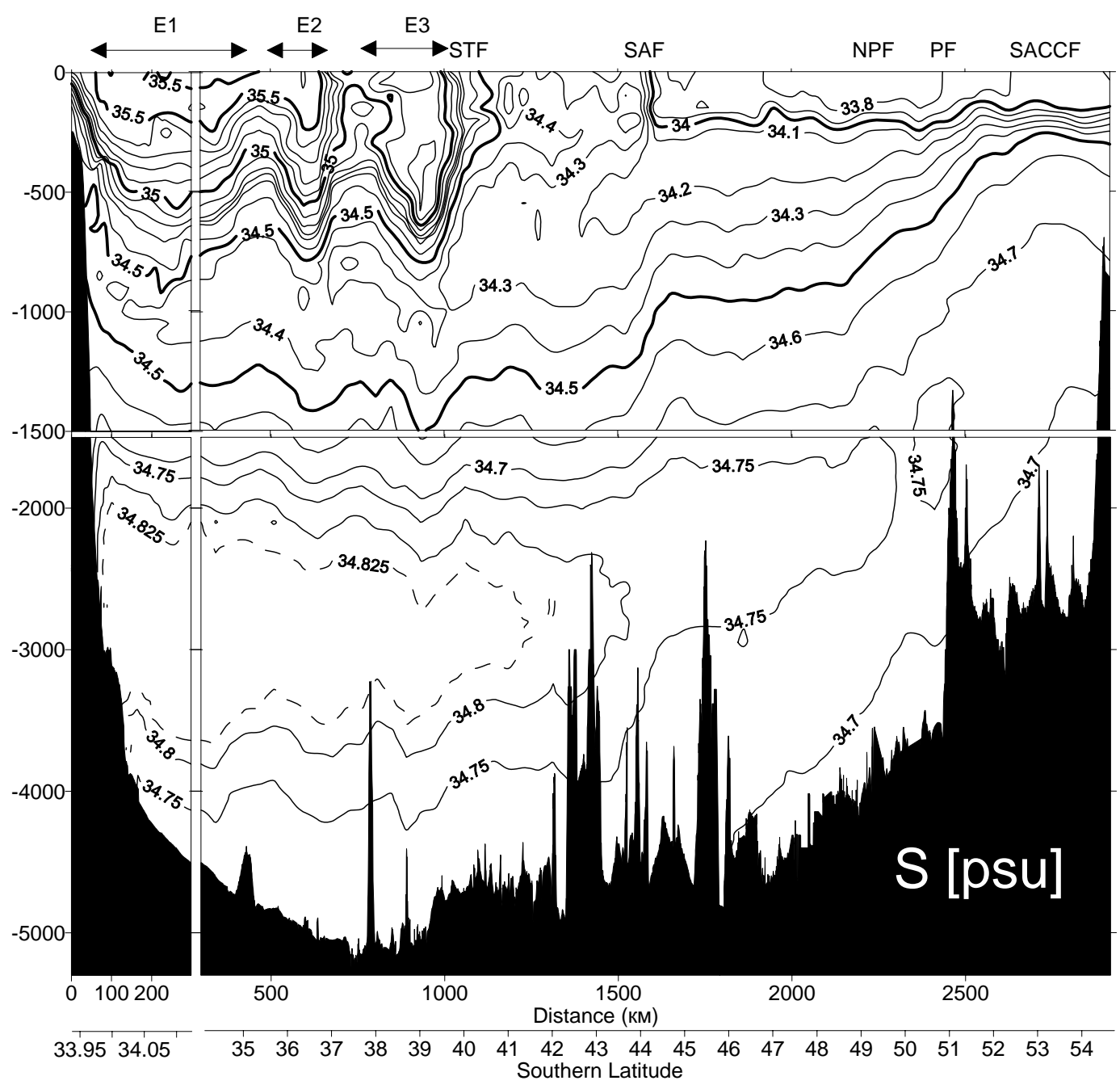

Figure 2b 


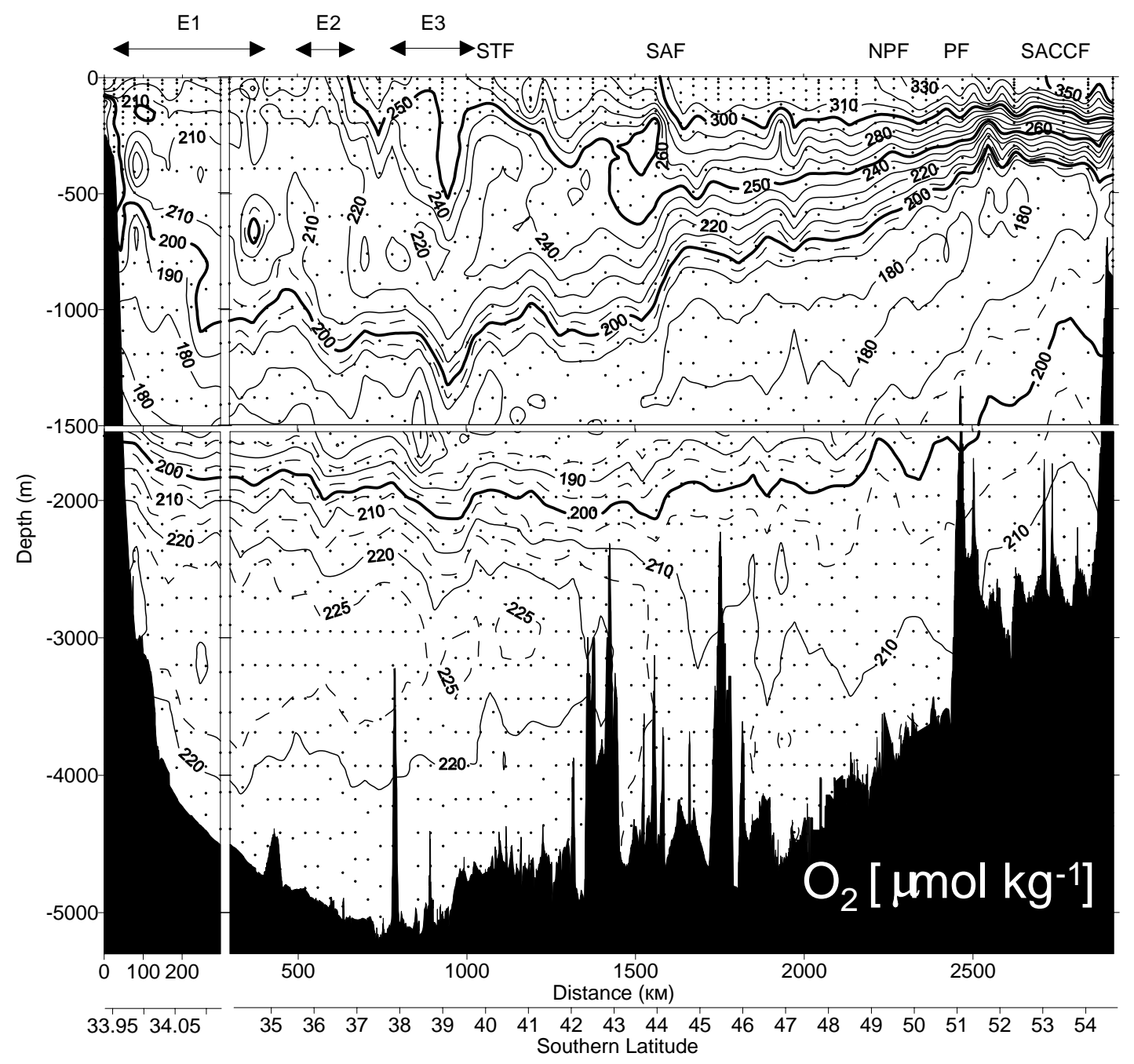

Figure 2c 


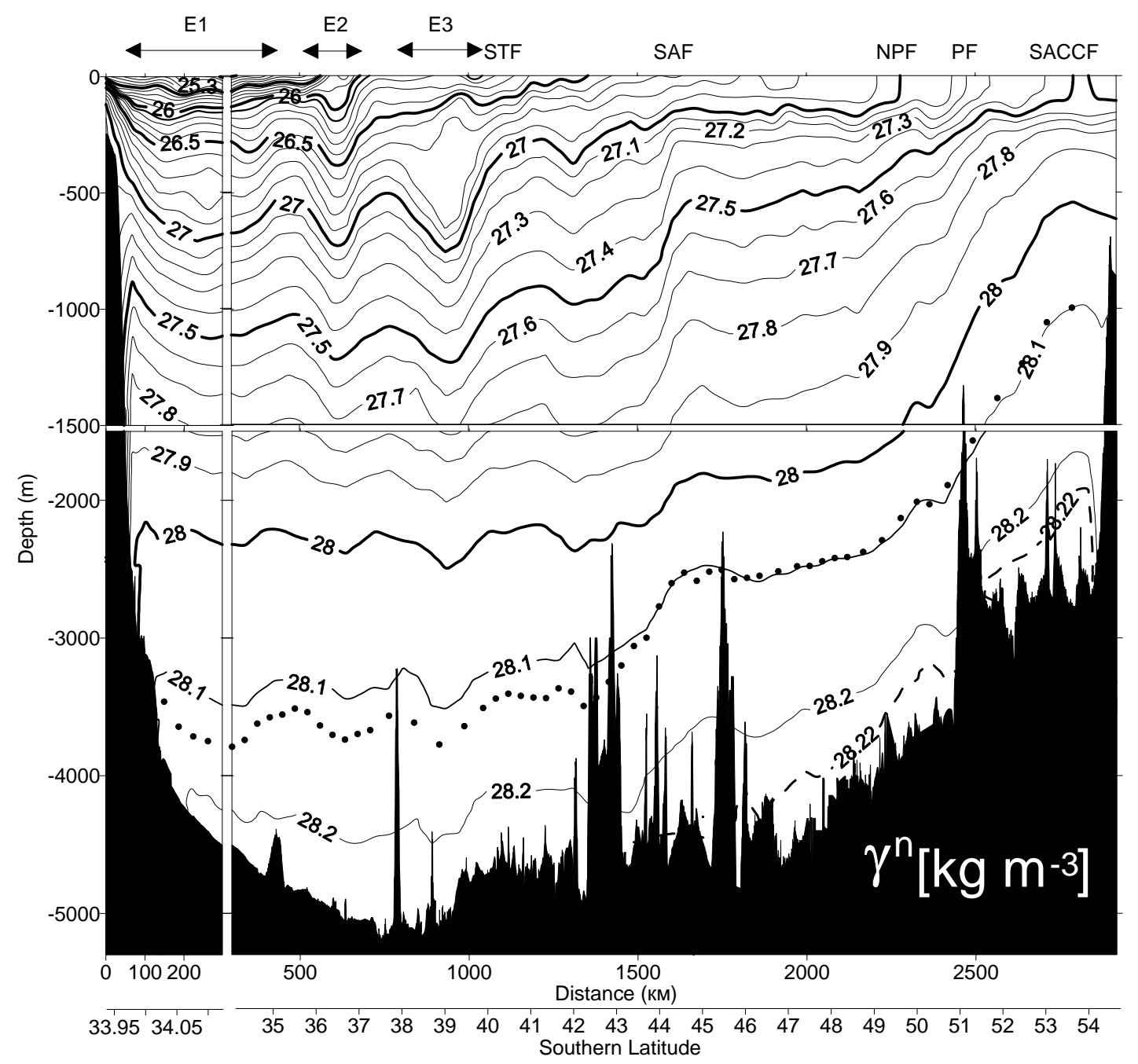

Figure 2d 


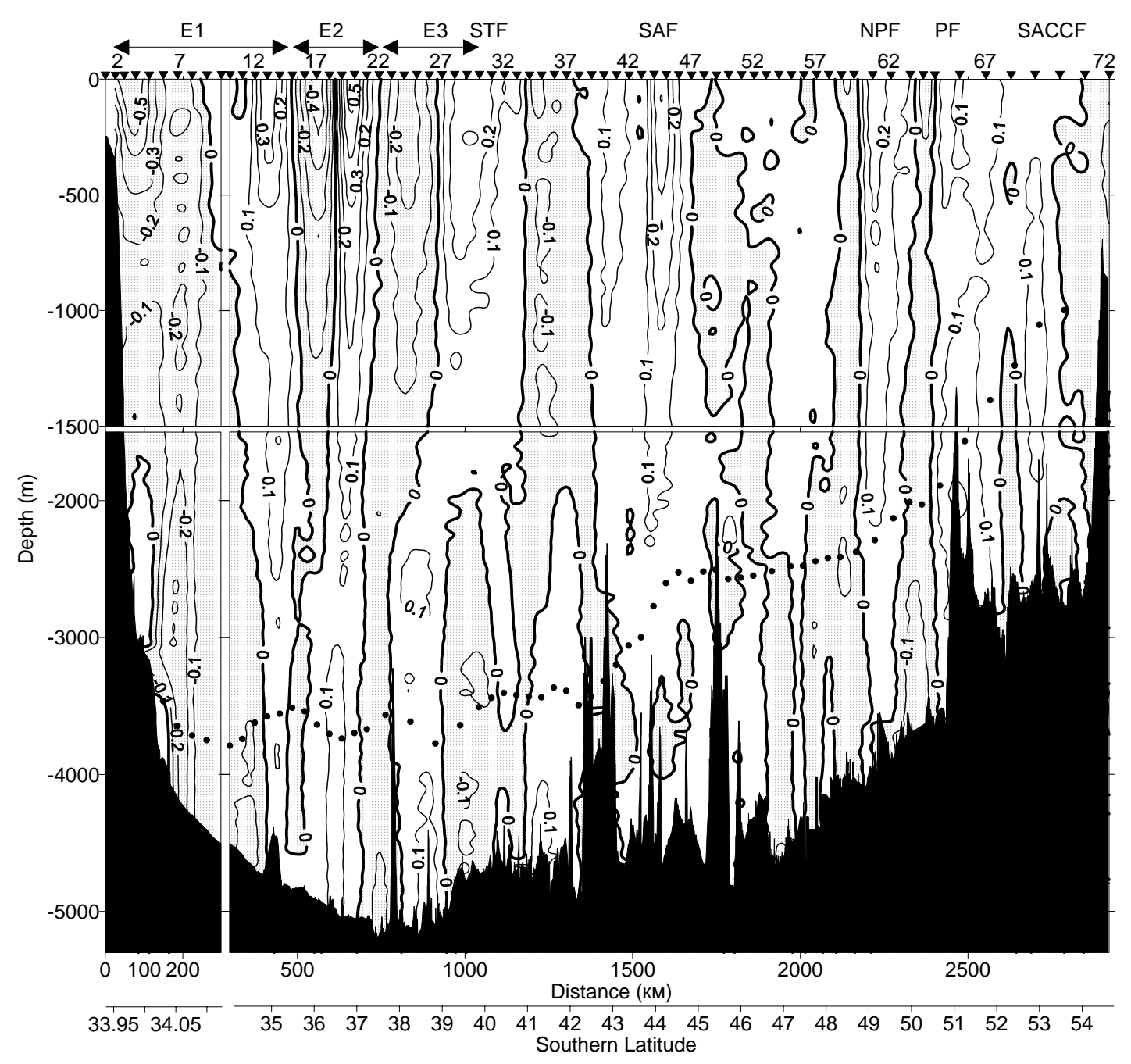

Figure 3a

Figure 3: (a) Vertical distribution of LADCP velocity component perpendicular to the cruise track (positive and non-shaded to the south-east), with the front positions, indication of eddies E1, E2, E3, and the upper limit of bottom water. (b) Same as (a) for the geostrophic velocity referenced to near-bottom LADCP values (absolute geostrophy). 


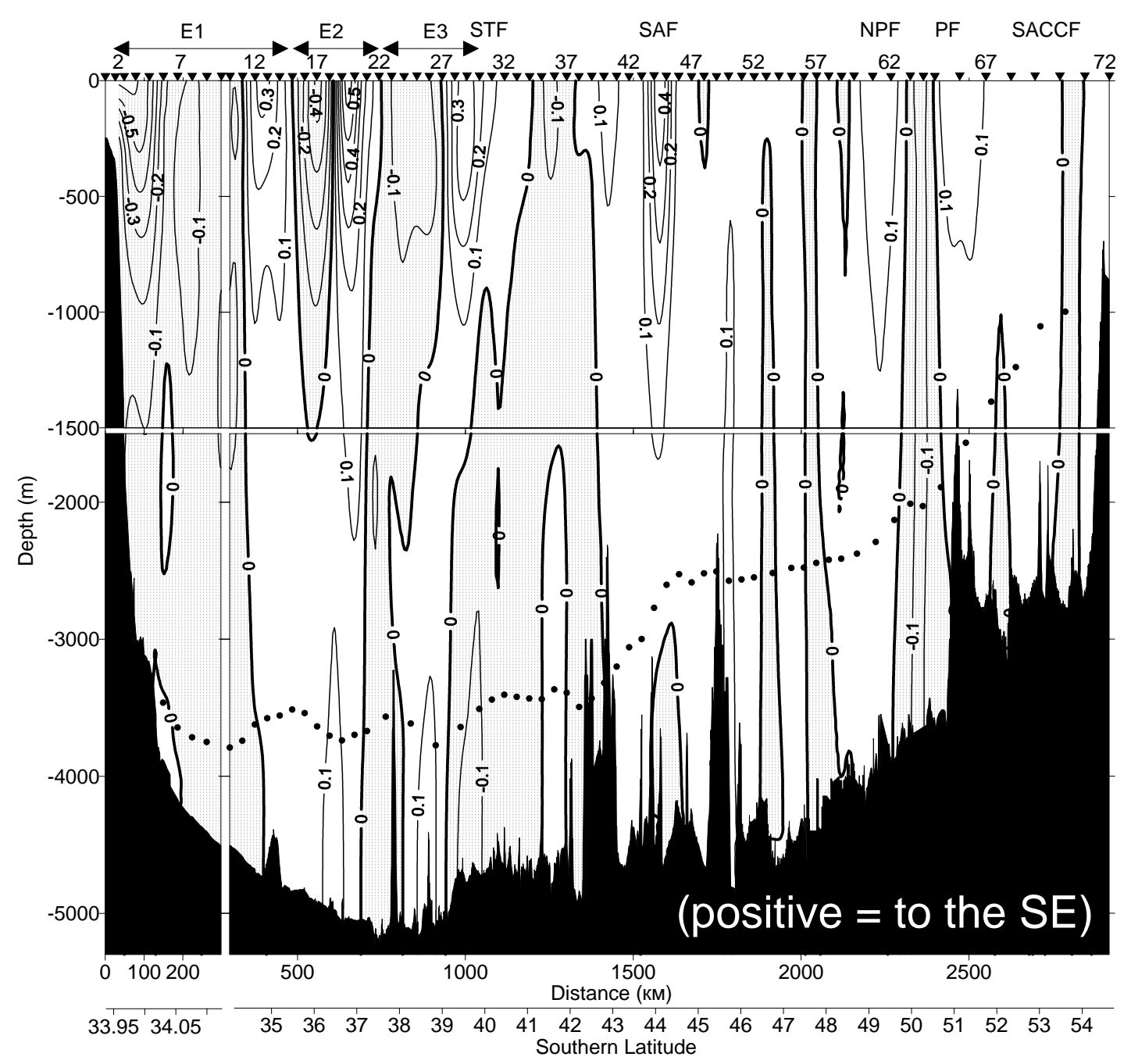

Figure 3b 

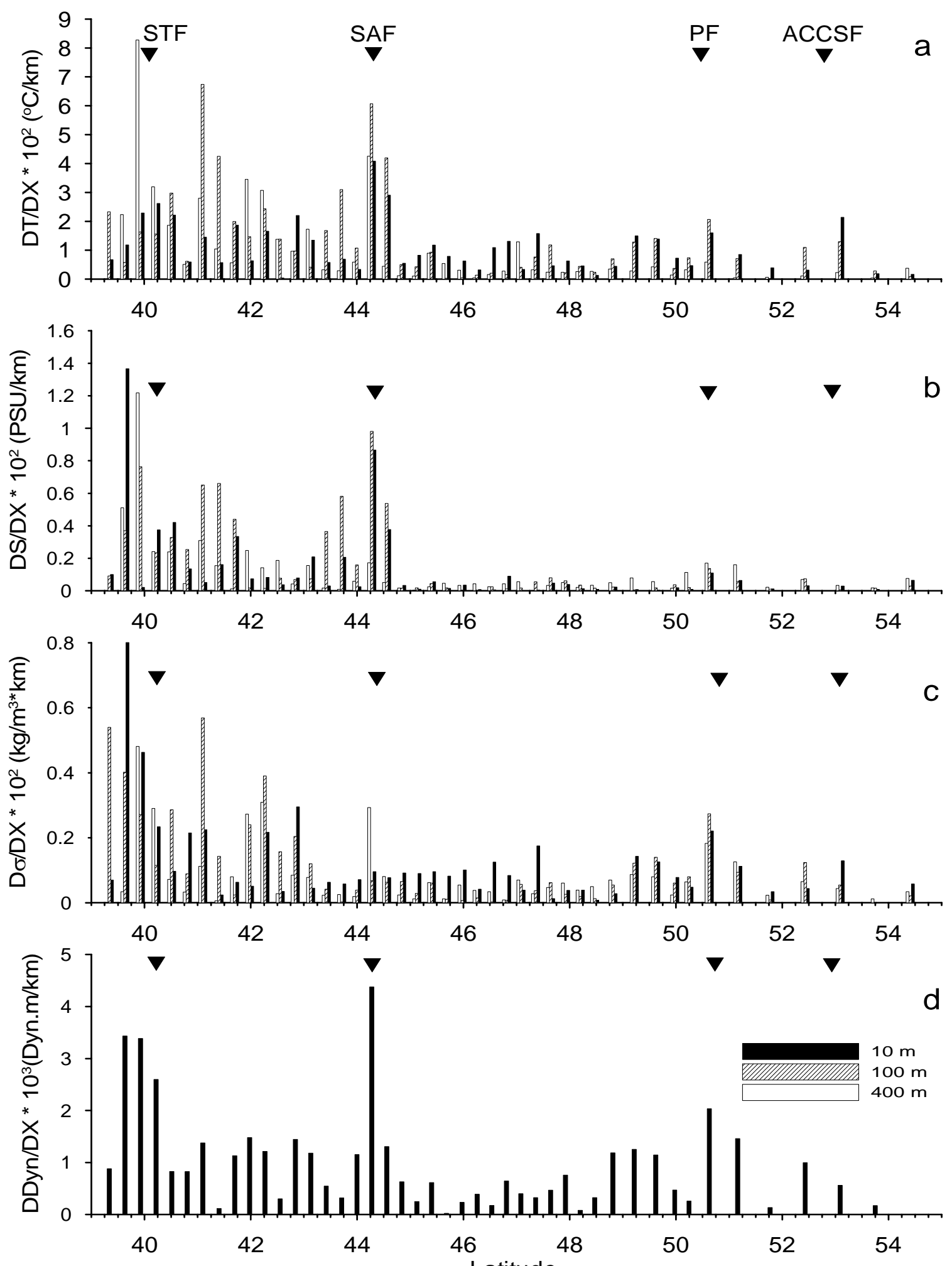

Figure 4: Lateral gradients of potential temperature (a), salinity (b), density (c), and dynamic height at 50 dbar relative to 2000 dbar (d), along the ASV-19 cruise track, at $10 \mathrm{~m}, 100$ $\mathrm{m}$, and $400 \mathrm{~m}$. The front locations deduced from the criteria of Orsi et al. (1995) are indicated by triangles. 


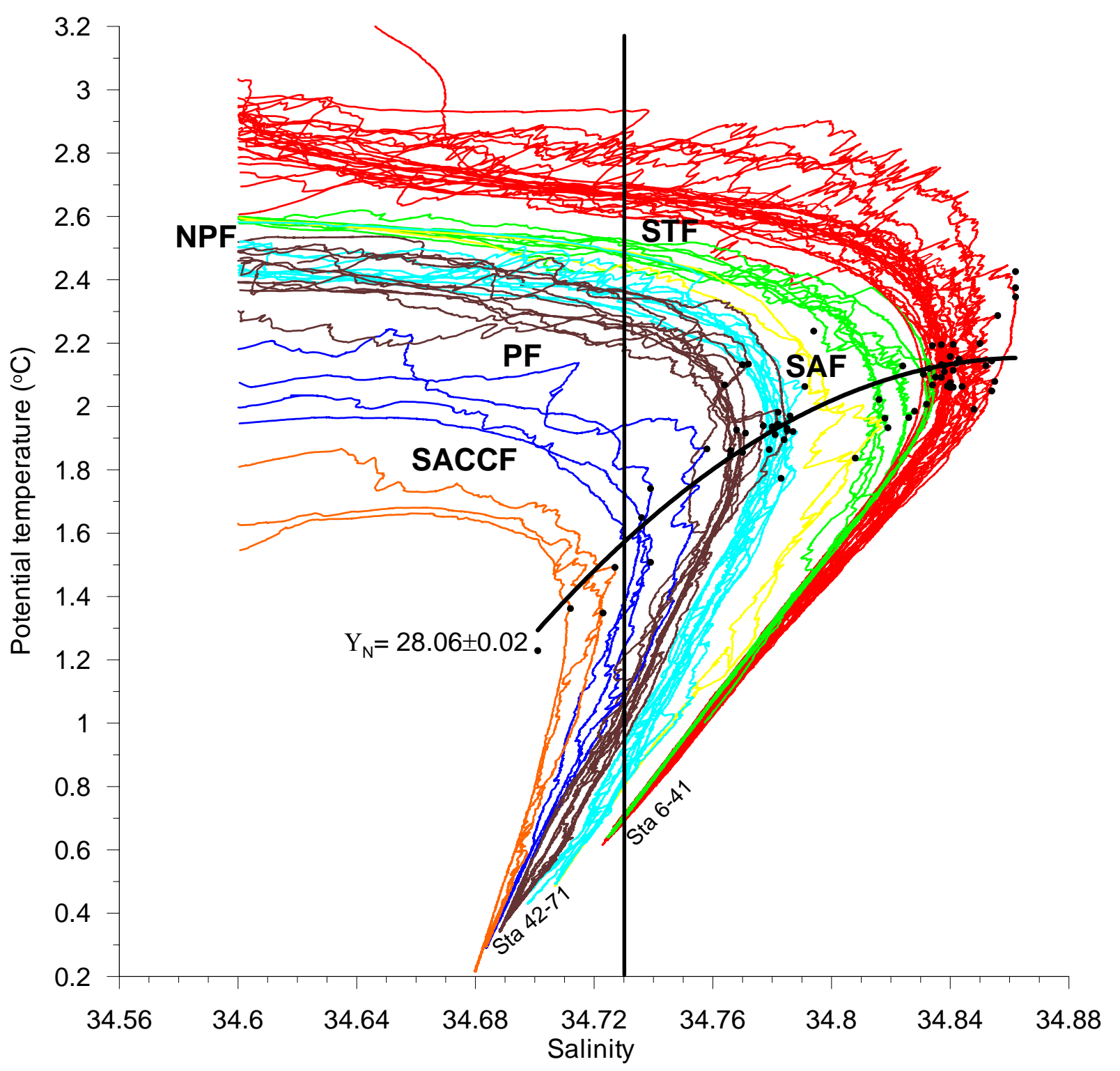

Figure 5 : Deep $\theta$-S diagram of all ASV-19 stations, limited by S=34.60. Different colors mark the subtropical domain and ACC frontal zones. The deep salinity maxima (black dots), their adjusted second order polynomial (black curve), and corresponding average $\gamma^{\mathrm{n}}$ value are reported. The vertical line at $S=34.73$ gives the maximum salinity in Drake Passage. The two station groups 6-41 and 42-71 illustrate the change of bottom properties across the Agulhas Ridge. 

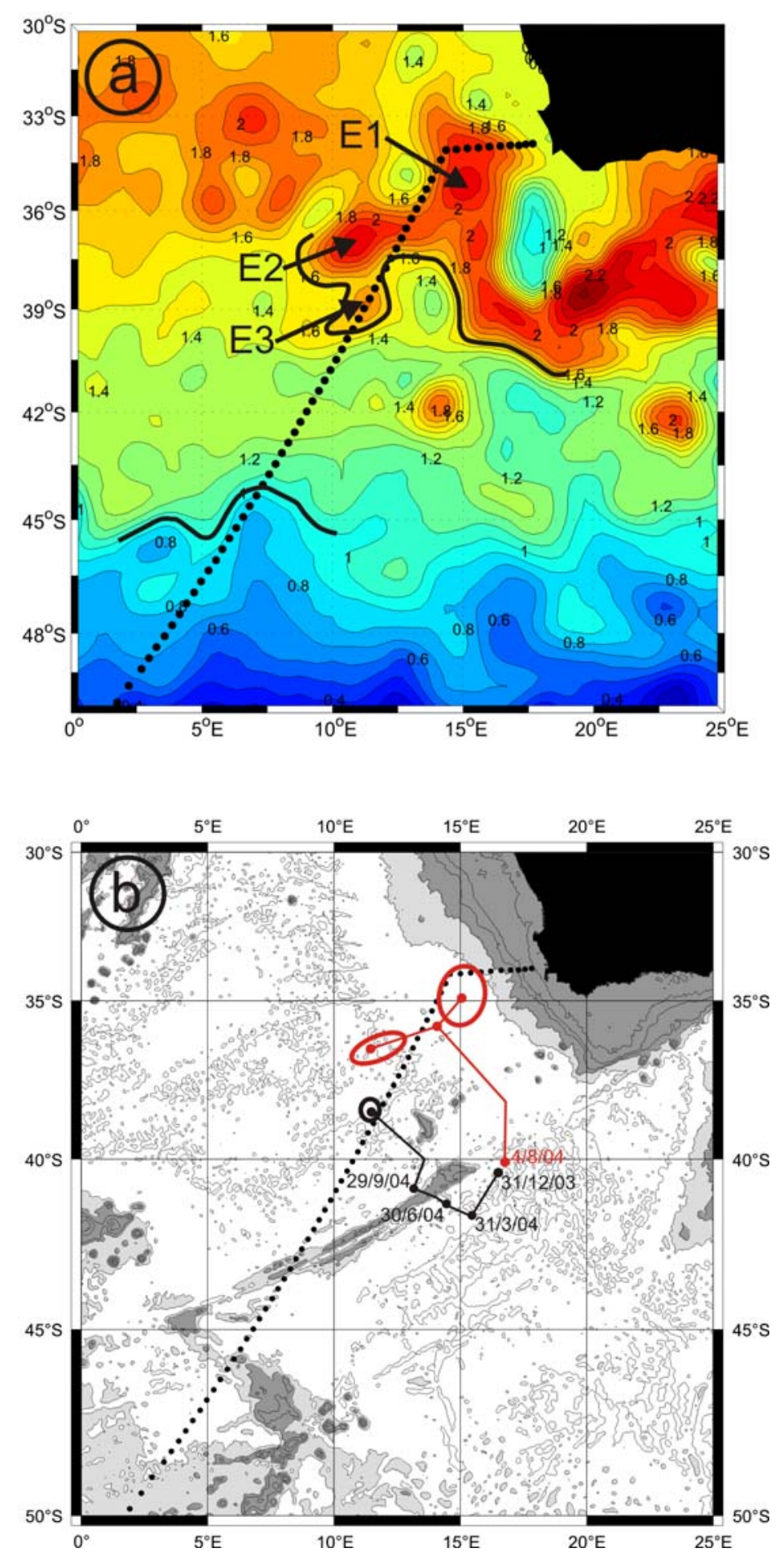

Figure $6:$ a) Sea surface height (SSH) field at the time of the cruise, showing eddies E1, E2 and E3. The cruise track and locations of the STF and SAF are superimposed. b) Map with shaded bathymetry showing the cruise track and trajectories of E1, E2, E3, with dates. 

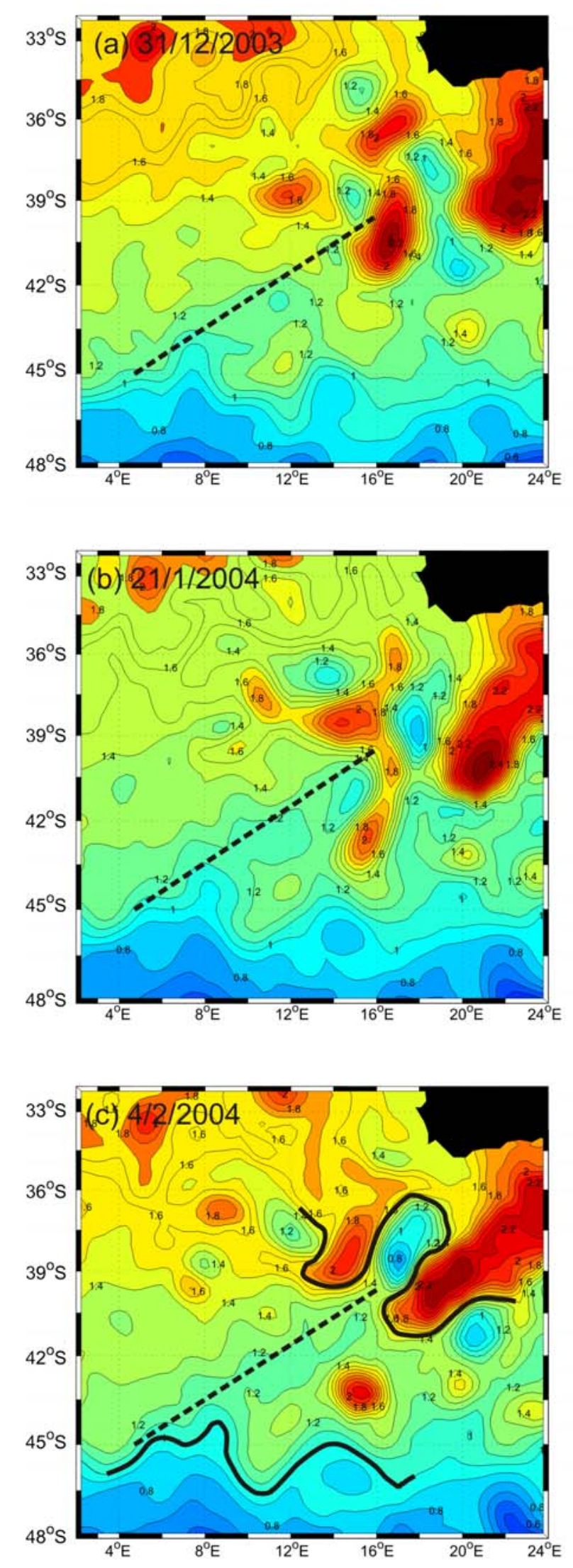

Figure 7 : Sequence of SSH maps showing the formation of eddy E3 (31/12/03, 21/1/04, 4/2/04). The black thick stippled lines schematises the Agulhas Ridge. 


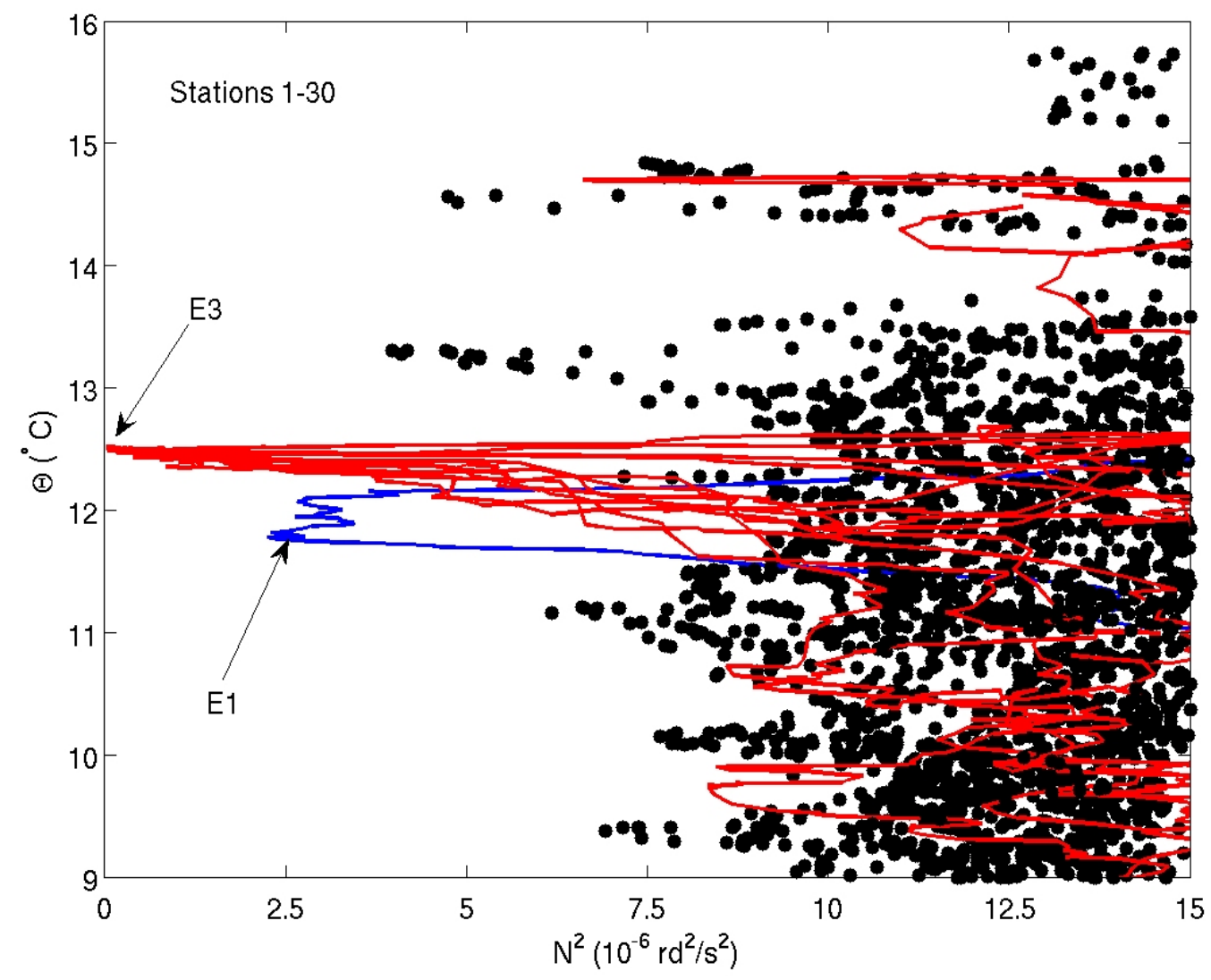

Figure 8 : Diagram of squared Brunt-Väisälä frequency versus temperature for stations north of the STF and temperature range $9-16^{\circ} \mathrm{C}$. Stations 9 (blue) and 24 to 29 (red) are shown by coloured continuous lines (instead of dots) to emphasize the homogeneous cores of E1 and E3. 


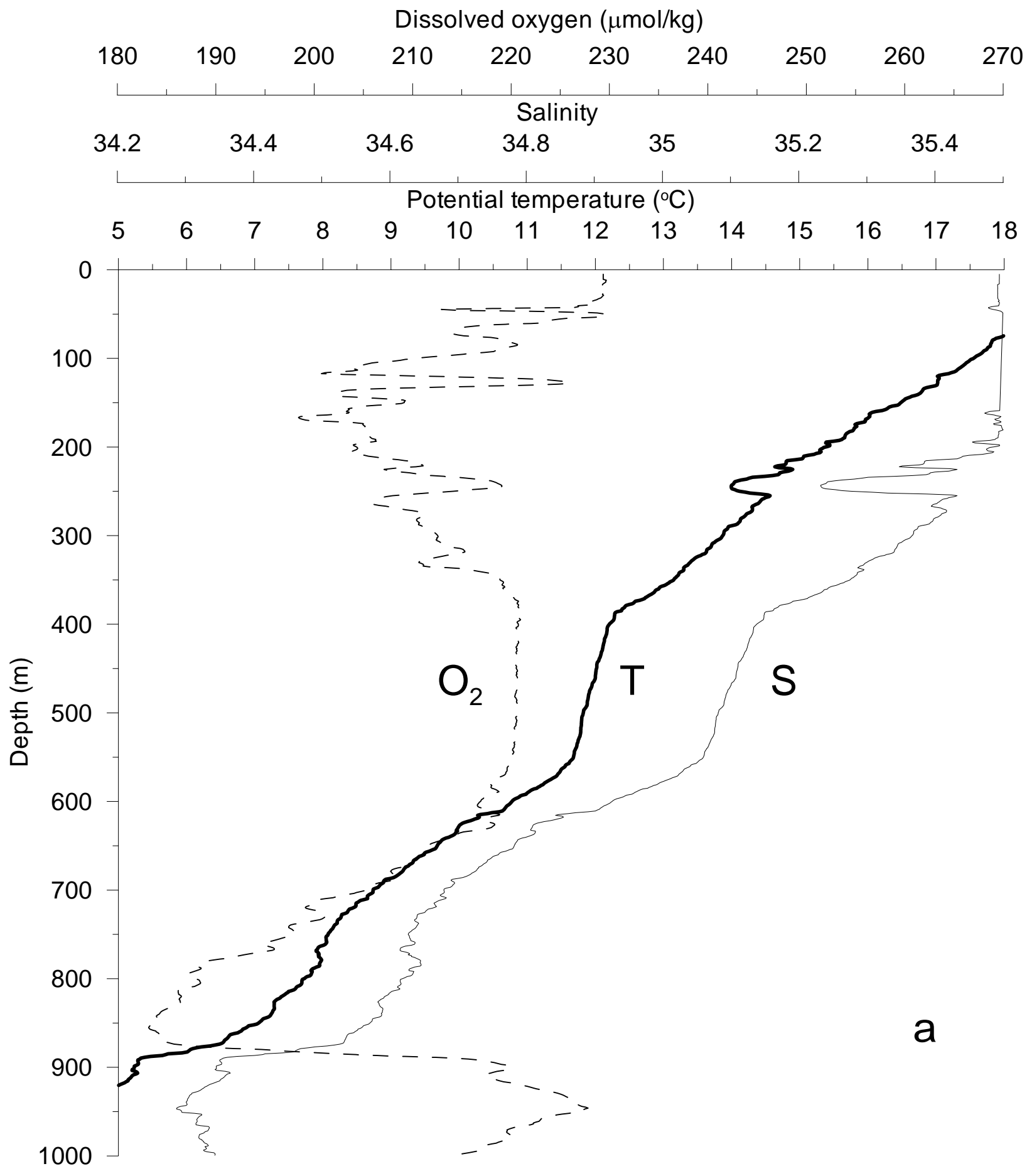

Figure 9a

Figure 9 : Vertical profiles of $\theta, \mathrm{S}$, and $\mathrm{O}_{2}$ in eddies $\mathrm{E} 1$ (a) and $\mathrm{E} 3$ (b). 


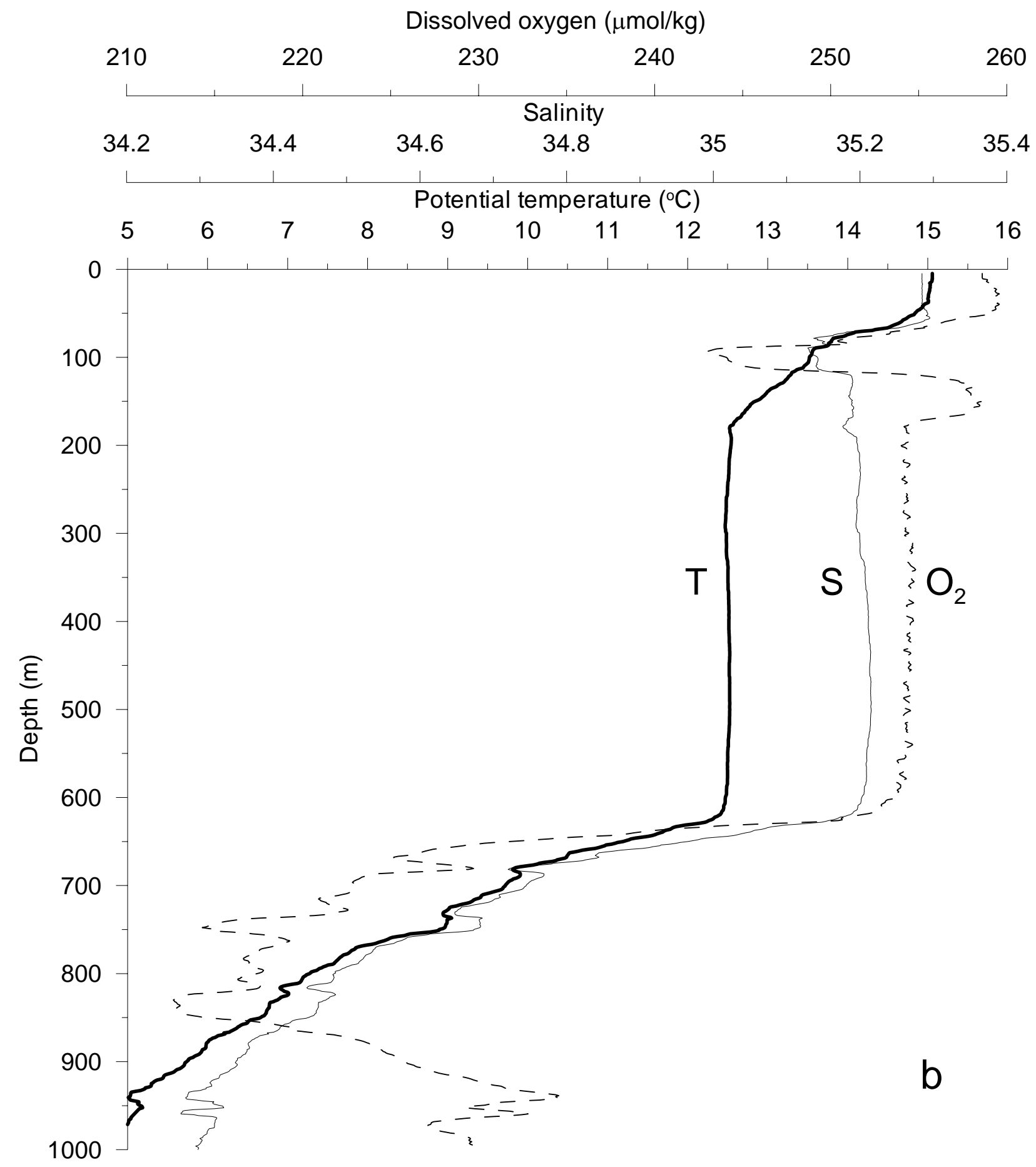

Figure 9b 


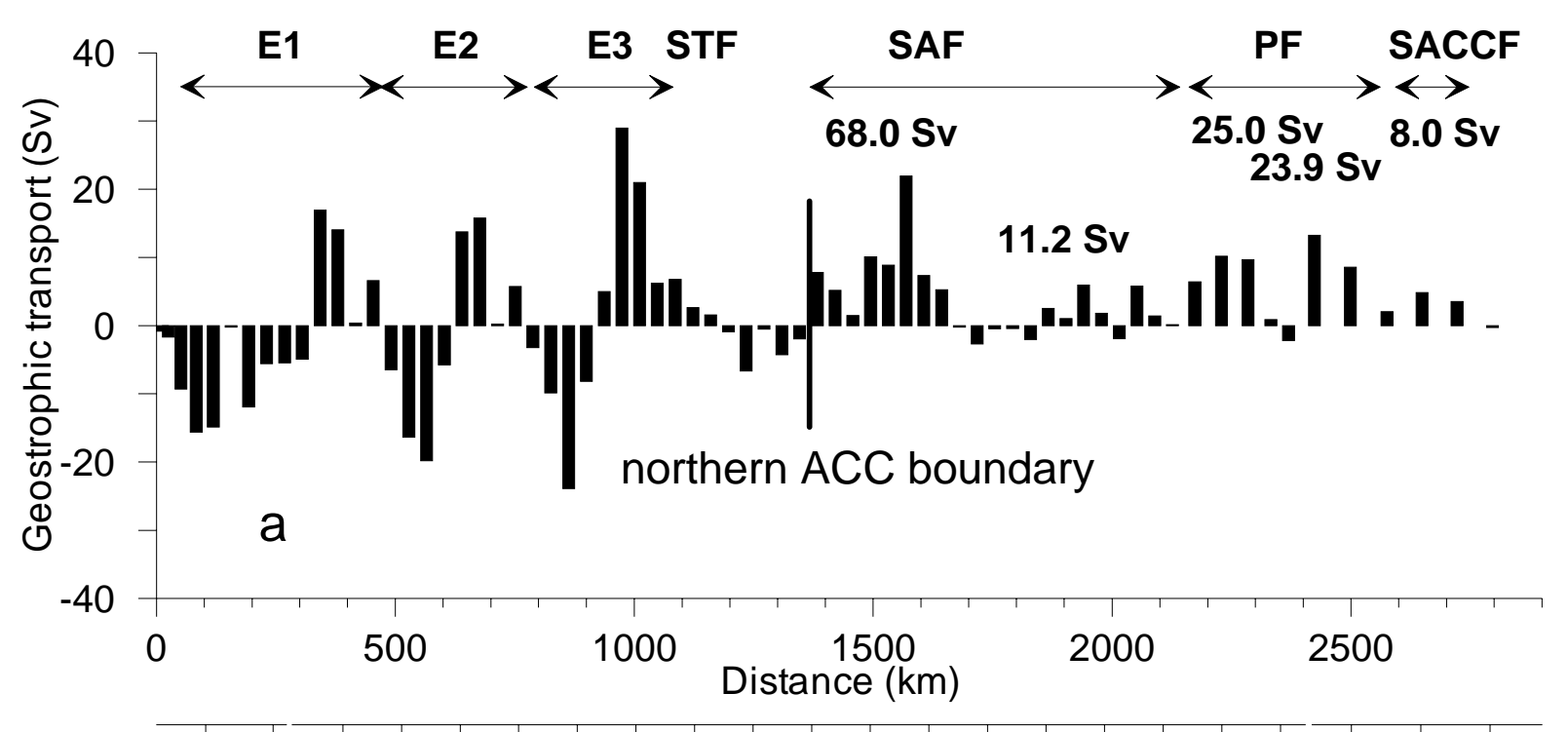

$3434.13536373839404142434445464748495051 \quad 52 \quad 53 \quad 54$ Southern Latitide

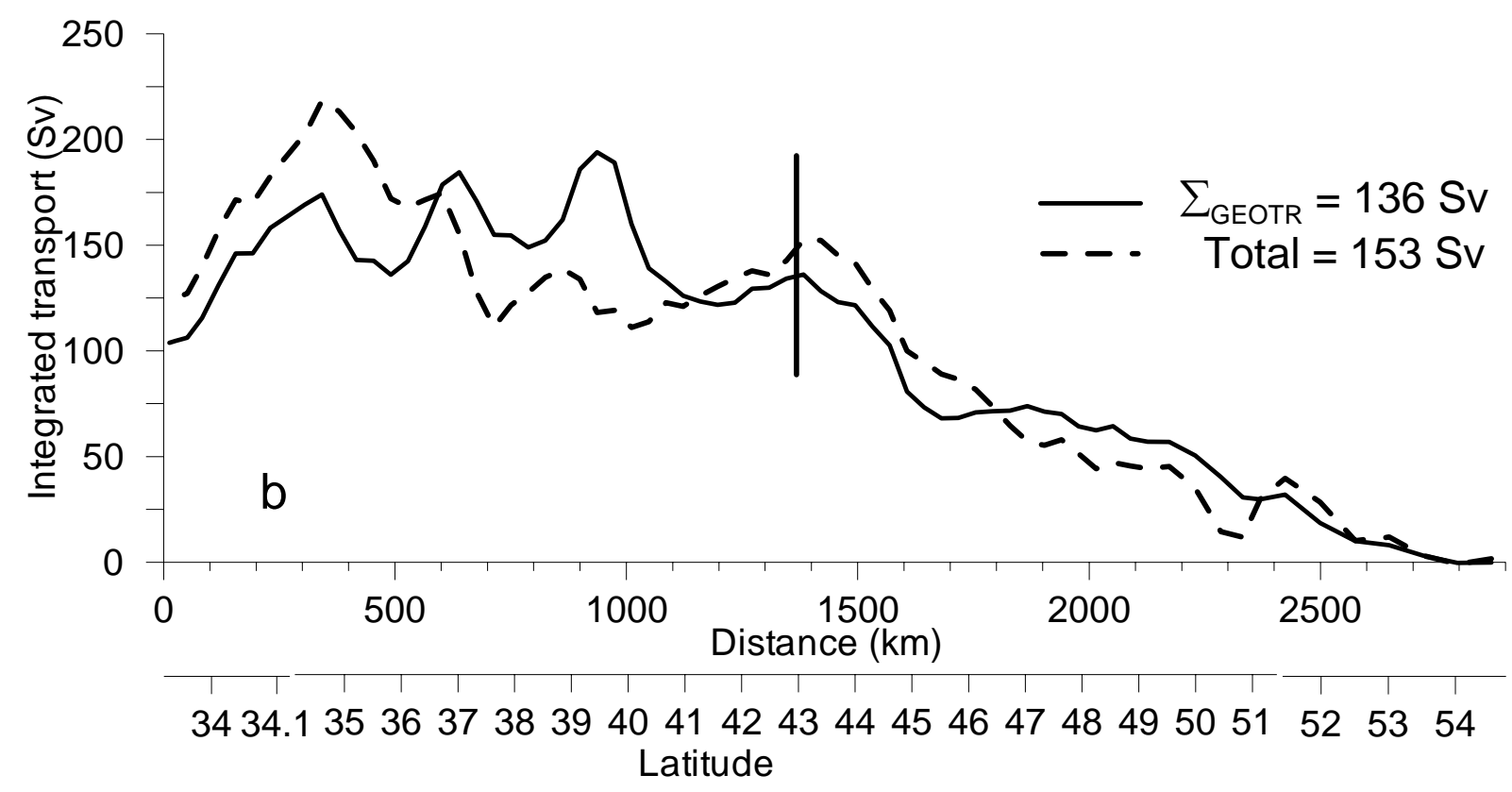

Figure 10 : (a) Cross-track baroclinic transport (geostrophy referenced to DCL). Positive is southeastward (southward) across the northeastward (zonally) oriented part of the section. (b) Along-track integrated transport of baroclinic velocities (continuous) and absolute geostrophic velocities (stippled). Vertical lines at $43^{\circ} \mathrm{S}$ show the northern limit used for ACC transport computations. 


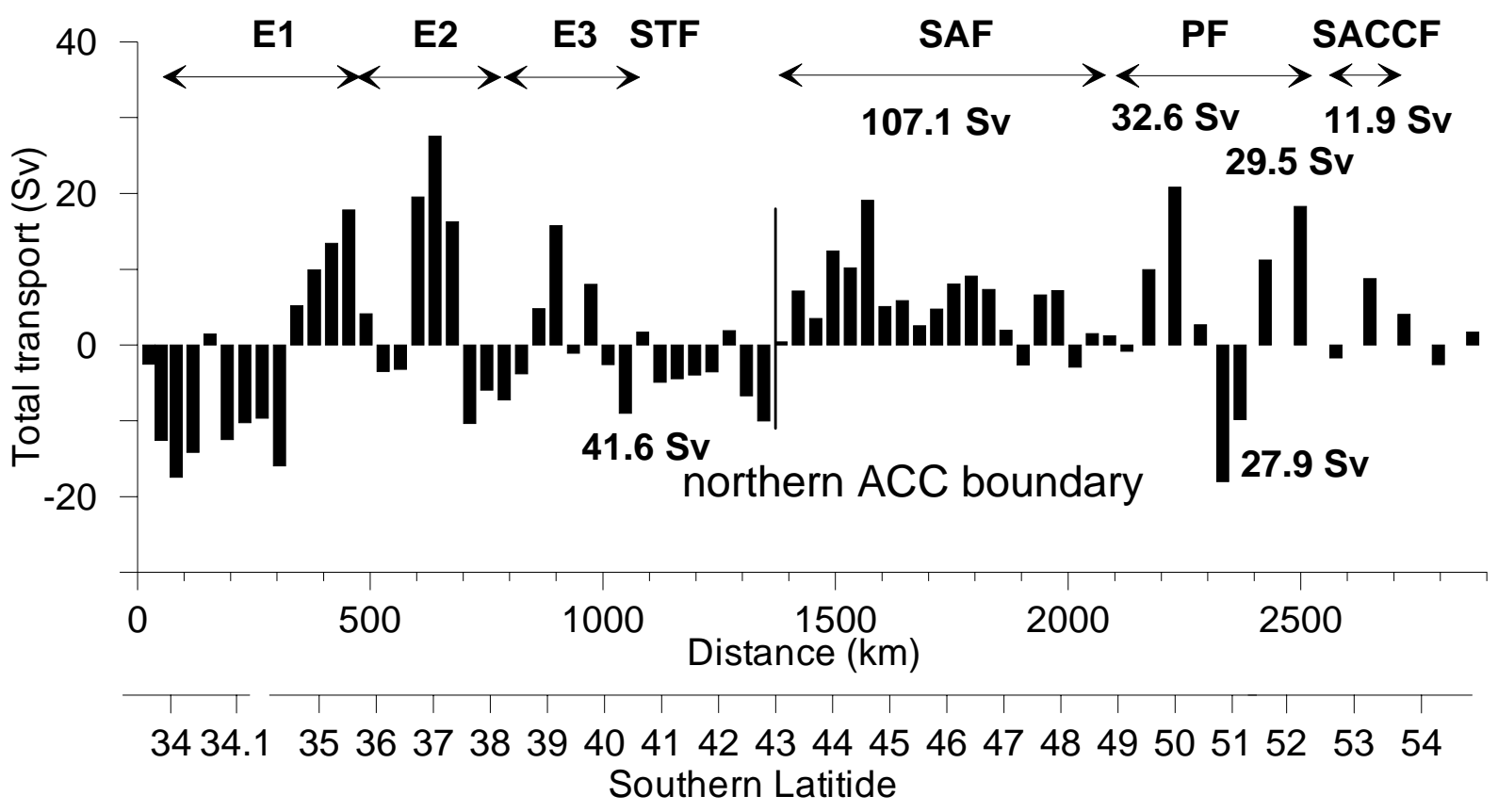

Figure 11 : Cross-track transport of absolute geostrophic velocities (referenced to near-bottom LADCP velocities). The vertical line at $43^{\circ} \mathrm{S}$ marks the northern limit used for ACC transport computations. 


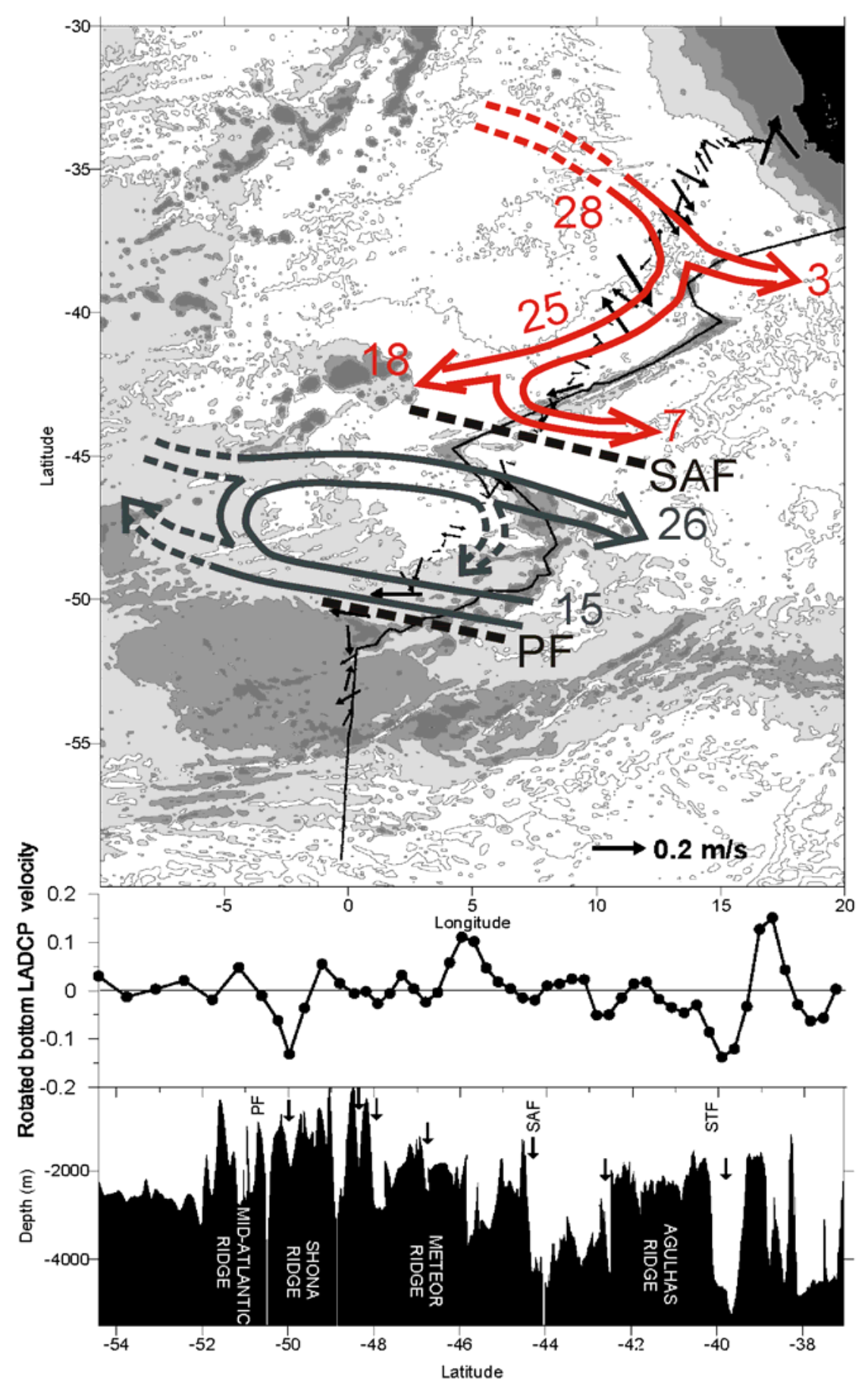

Figure 12 : Top panel: Proposed schematic circulation of layer $\theta<1.5^{\circ} \mathrm{C}$, with transport estimates in Sverdrup. Also shown are the bottom LADCP velocity vectors.

Middle panel: Cross-track bottom LADCP velocities (positive eastward and southward). Lower panel: Bathymetry along the crest-line separating the Cape Basin and Agulhas Basin. The track of this line is shown in the top panel. Vertical arrows show possible deep passages for bottom currents. 


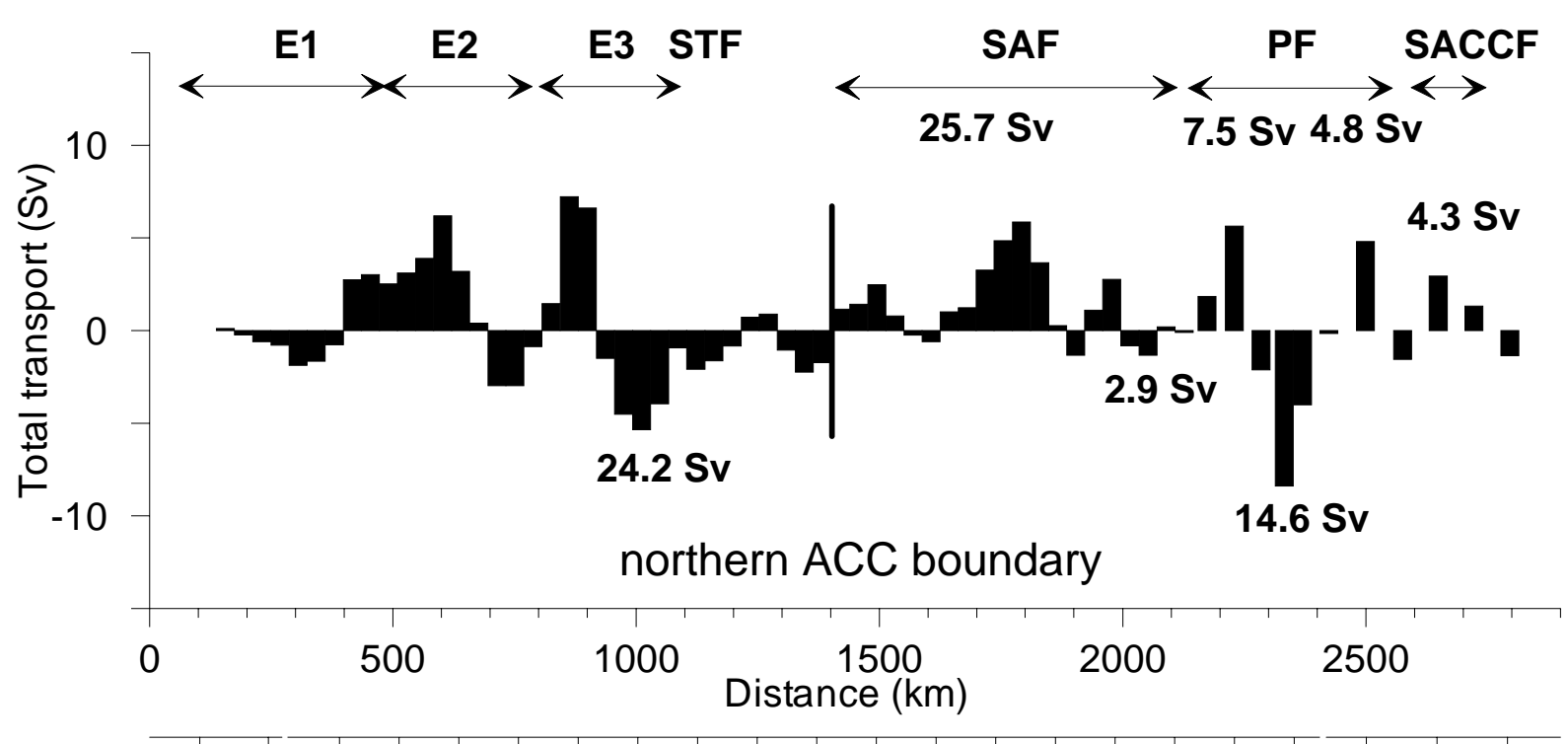

$3434.1353637383940414243444546474849505152 \quad 53 \quad 54$ Southern Latitide

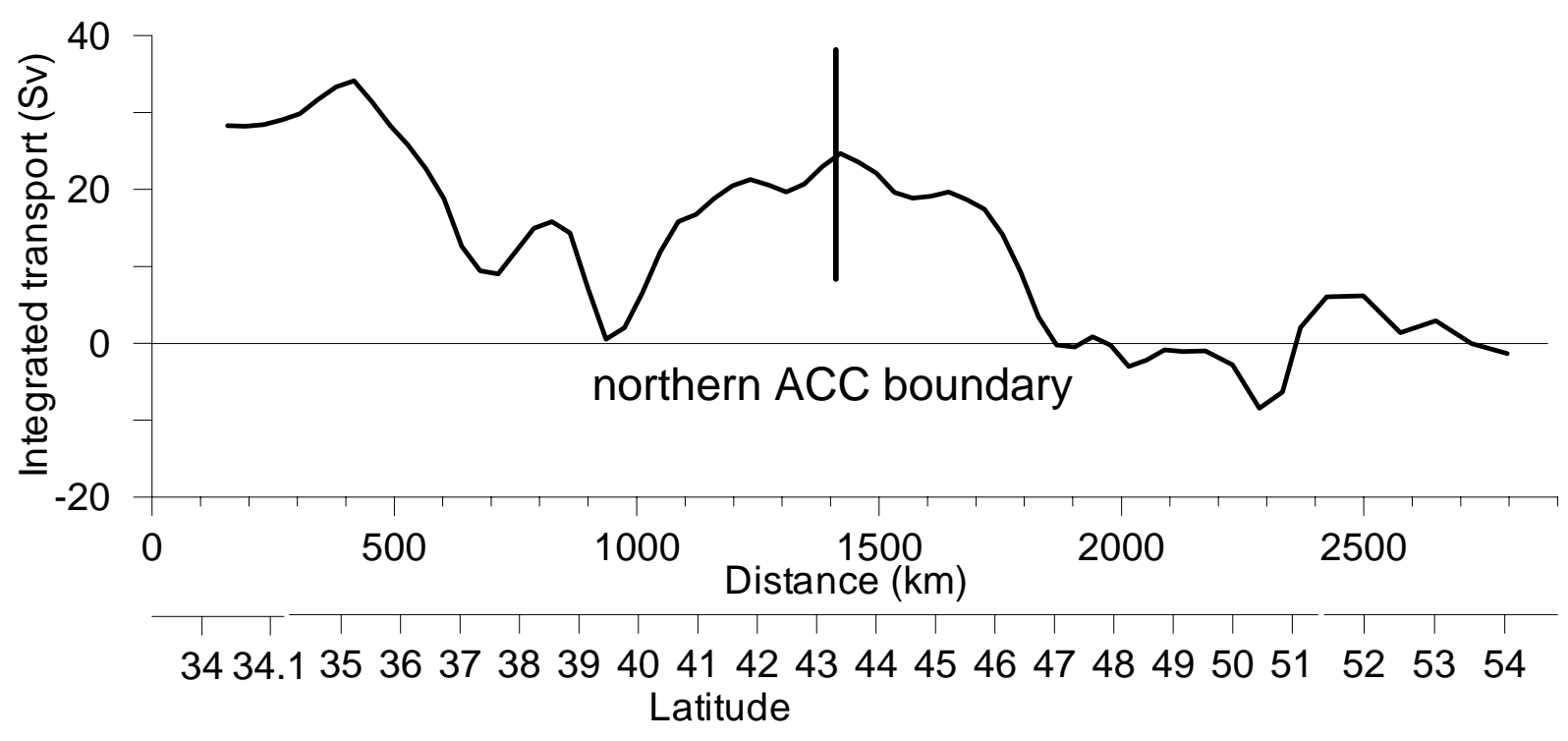

Figure $13:$ : (a) Cross-track absolute transport (computed using absolute geostrophic velocities) in the bottom layer $\theta<1.5^{\circ} \mathrm{C}$. (b) Along-track integrated transport of layer $\theta<1.5^{\circ} \mathrm{C}$. Vertical lines at $43^{\circ} \mathrm{S}$ show the northern ACC boundary. 